\title{
CALIX[4]ARENES, MOLECULAR PLATFORMS FOR SUPRAMOLECULAR STRUCTURES
}

\author{
L. C. GROENEN and D. N. REINHOUDT \\ Laboratory of Organic Chemistry \\ University of Twente \\ P.O.Box 217 \\ 7500 AE Enschede \\ The Netherlands
}

\begin{abstract}
A new strategy for the synthesis of receptor molecules comprises the combination of medium-sized molecules to which functional groups for intermolecular interactions can be attached. Most efforts concern the functionalization of calix[4]arenes, but other building blocks like cyclodextrins and octols are used as well. Selective mono-, 1,2-di, 1,3-di-, and tetraalkylation of calix[4]arenes can be achieved by variation of the alkylation conditions. The calix[4]arenes can be (selectively) functionalized at the "upper rim" by a variety of methods including ipso-nitration. Combination of the calix[4]arenes with crown ethers to calixcrowns gave receptors with a high $\mathrm{K}^{+} / \mathrm{Na}^{+}$-selectivity and with teryhenyls calixspherands were obtained that form kinetically stable complexes with $\mathrm{Na}^{+}, \mathrm{K}^{+}$and $\mathrm{Rb}^{+}$. Bridging of calix[4]arene with a salophene moiety gave a receptor for urea that can effectively transport urea through a supported liquid membrane. Calix[4]arenes can be combined covalently to double and triple calixarenes and with selectively functionalized octols. When substituted with hydrogen bond donors and acceptors like 2-pyridone, calixarenes undergo self-association to larger aggregrates.
\end{abstract}

\section{Introduction}

Nature constructs biological receptors by combining large numbers of simple building blocks, which carry different functional groups, into large molecules that form threedimensional structures by specific intramolecular interactions between different parts of the linear structure. Amino acids are combined to proteins, nucleosides to DNA or RNA and monosaccharides to carbohydrates. The recognition sites are formed by a very precise stereochemistry and the recognition process is often very efficient. 
However, this is achieved at the expense of a high molecular weight.

Synthetic receptors are obtained by de novo synthesis using modern synthetic methodologies, which allow almost unlimited variation. The strategy focusses on the complementarity of functional groups between receptor and guest species and aims for minimal reaction steps and molecular weights. The drawback is that for each individual guest a new synthetic pathway has to be developed; the learning experience is not efficiently accumulated.

We are currently exploring an approach that is a compromise of these two extremes in that we start from medium-sized molecules that we use as frameworks or platforms to which the functional groups for intermolecular interactions can be attached. In a later stage several of these platforms can be connected either by covalent or non-covalent bonds to build up larger structures. Examples of such molecular building blocks are cyclodextrins (1), the octols or Högberg compounds (2) and the calixarenes (3). Cyclodextrins (1) are being used by quite a few groups as starting structures for the synthesis of host molecules and enzyme models [1]. The octols 2 have mainly been used by Cram and coworkers as building blocks for cavitands [2]. A few years ago we have become interested in the calixarenes (3) as promising new building platforms $[2,3]$, especially the calix [4]arenes $(3, n=4)$, and more recently also the calix[6]arenes $(3, n$ $=6$ ).

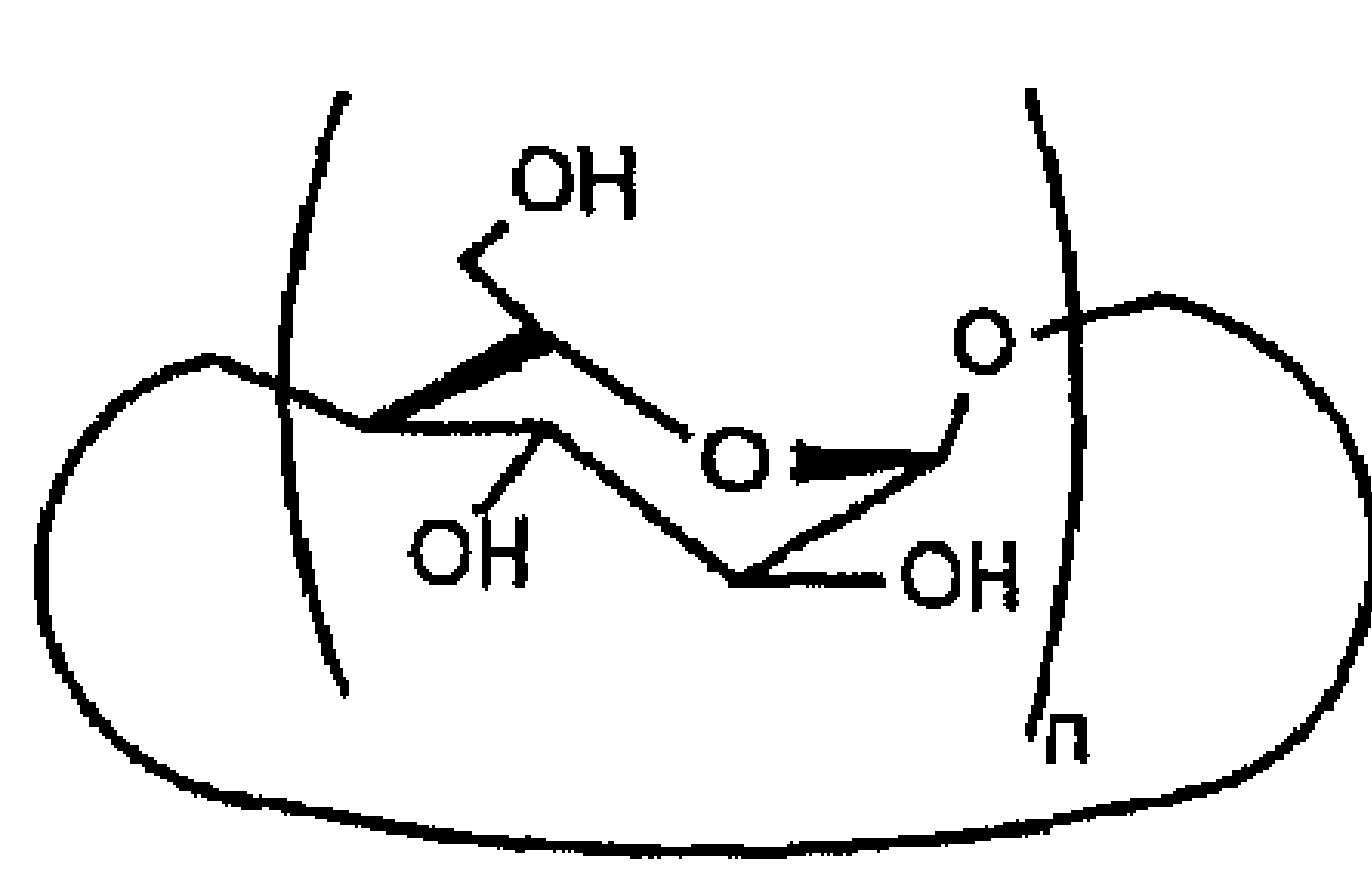

1

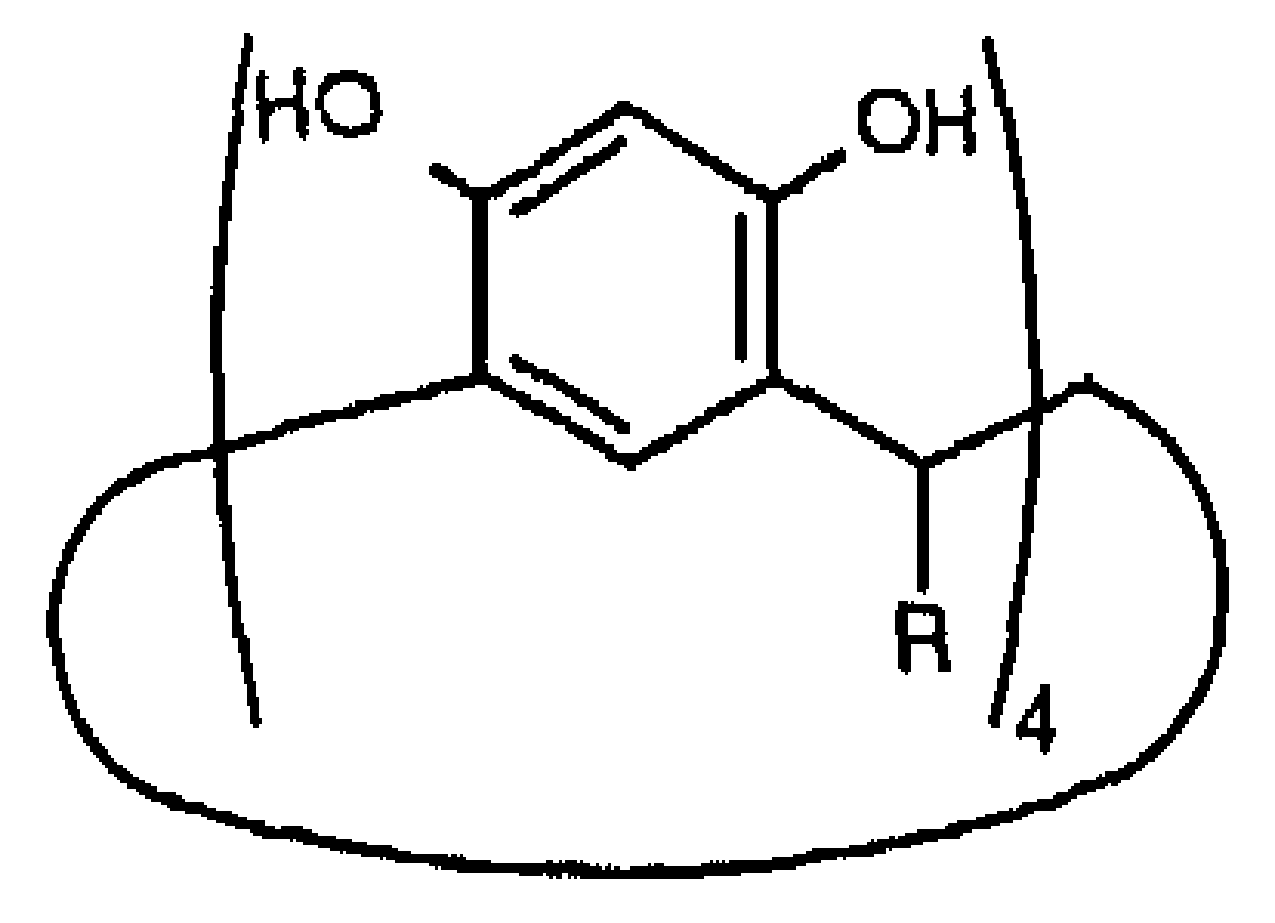

2

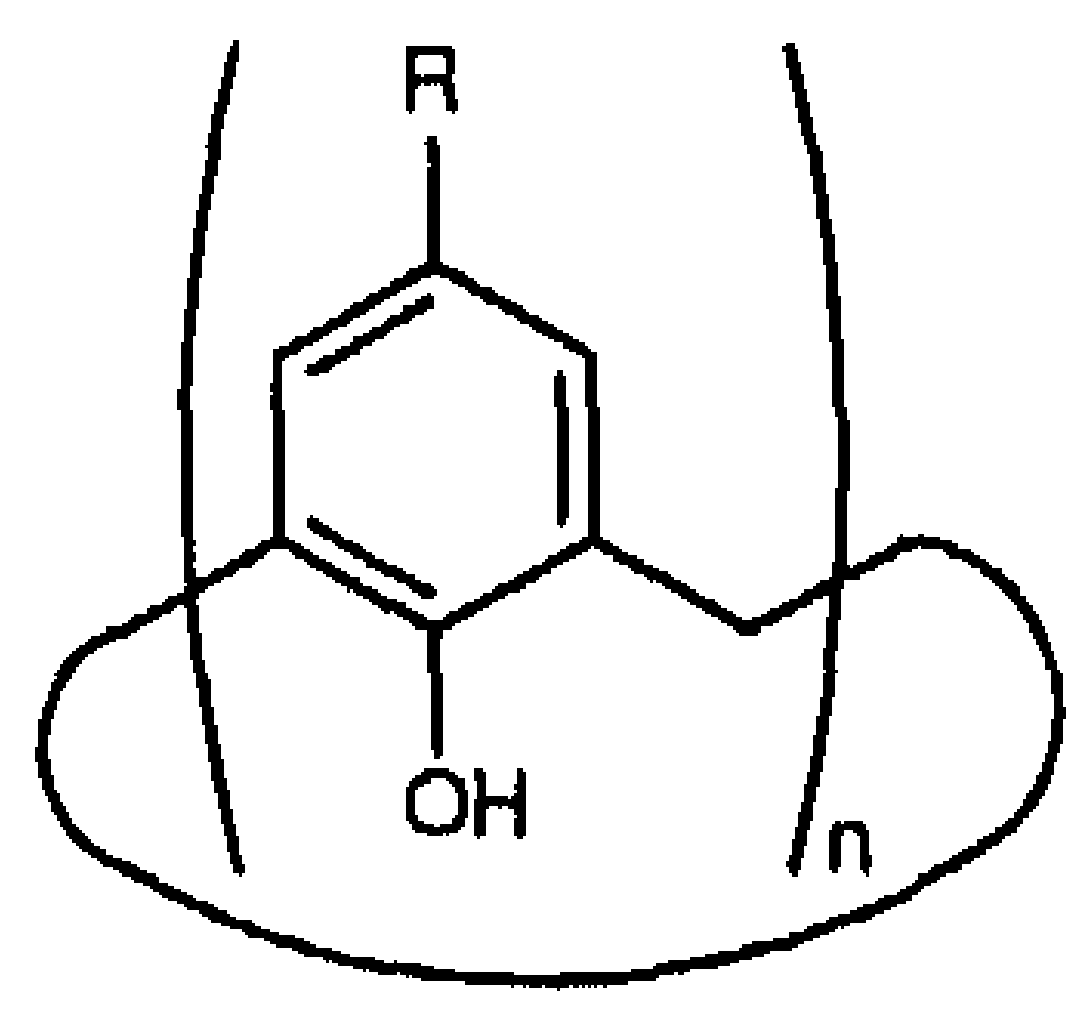

3

In this article we will outline our efforts towards the shaping of these molecular platforms to our needs. Although we have found some interesting new results for the selective functionalization of $\beta$-cyclodextrin $(1, n=7)$ and the octols 2 , our main research activity is dedicated to calix[4]arenes and our results in this field will be discussed in detail. Beside new methods for selective functionalization of calix [4]arenes, also ways for controlling the conformation of the calix[4]arene and thus the shape of the building block will be discussed. Finally, a few examples of the coupling of calix[4]arenes with other building blocks will be described. 


\section{Selective Functionalization of $\beta$-Cyclodextrin}

Recently, the synthesis of the heptasilylated $\beta$-cyclodextrin 4 has been reported [4]. This compound, which is soluble in organic solvents, can be monotosylated at the secondary side in $30 \%$ yield by reaction with one equivalent of $\mathrm{NaH}$ in tetrahydrofuran and treatment with $p$-tosyl chloride (Scheme 1). Subsequent epoxidation and ringopening with $\mathrm{LiN}_{3}$ afforded in good yield the monoazide 5, which, after reduction, can be used in coupling reactions with other building blocks [5].

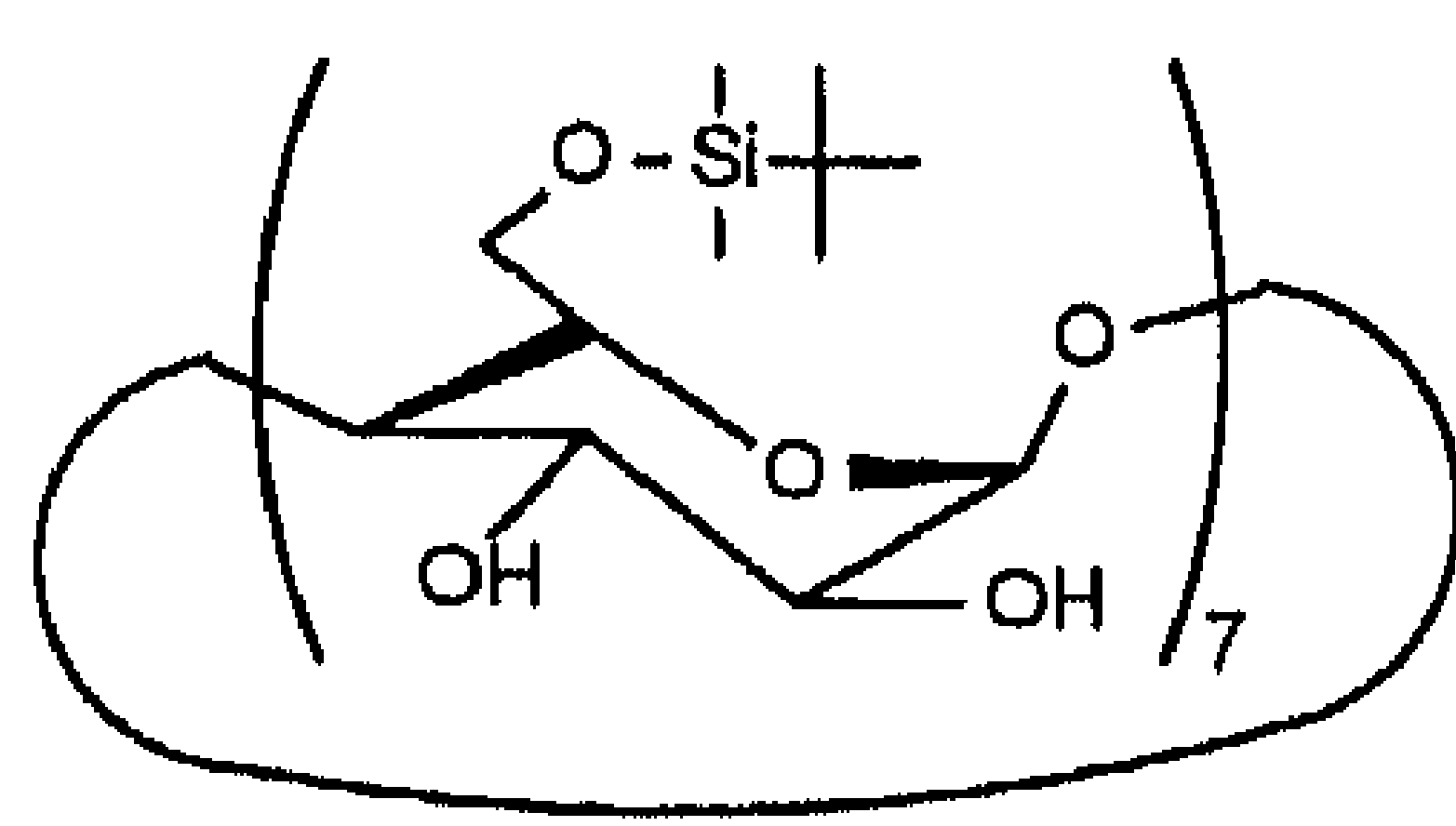

1. $1 \mathrm{eq} \mathrm{NaH}$ $\mathrm{p}-\mathrm{Tos} \mathrm{Cl}$

2. base 3. $\operatorname{LiN}_{3}$

4

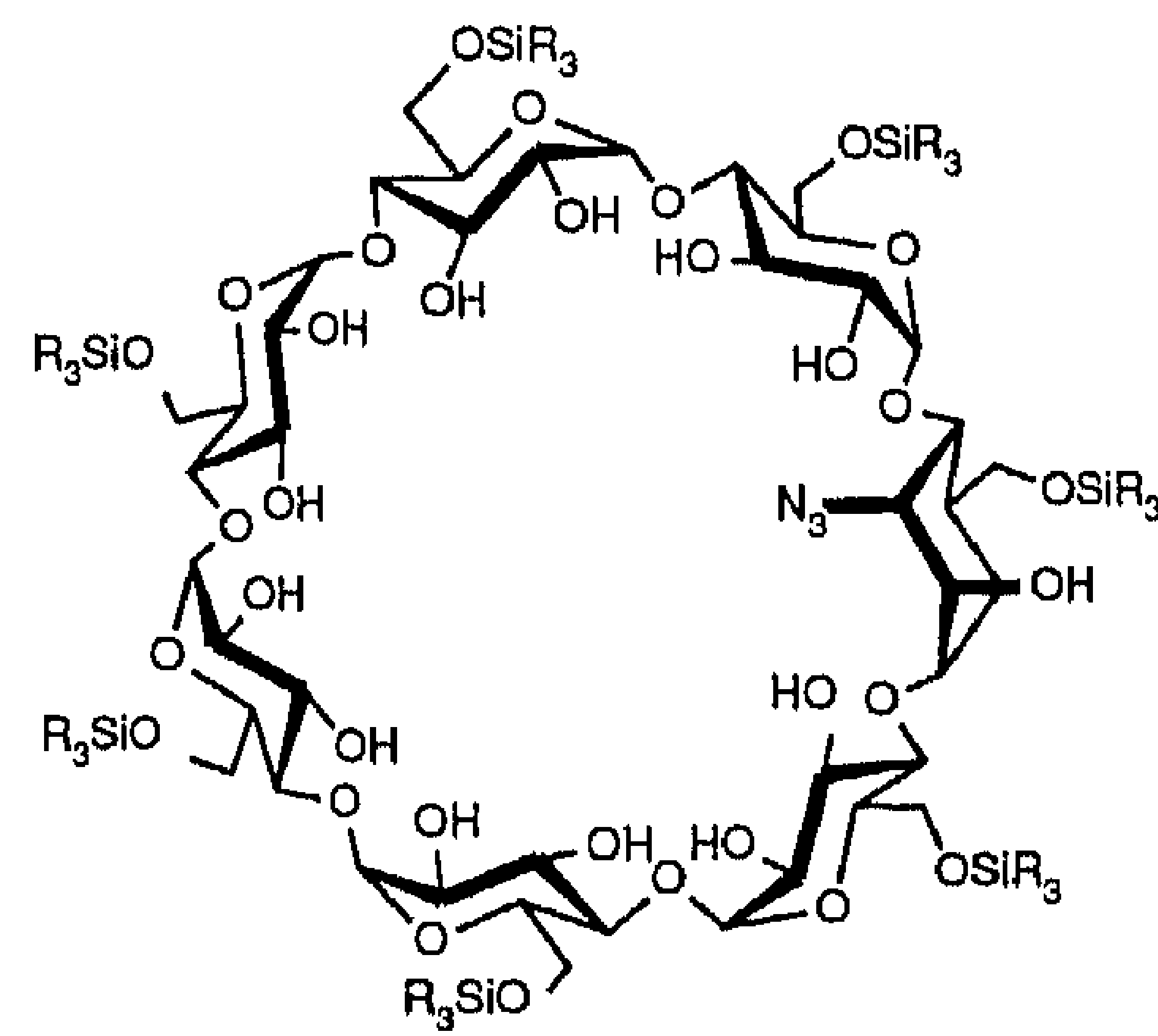

5

Scheme 1

\section{Selective Functionalization of Octols}

Two of the four bromo atoms of the tribridged octol 6 [6] can be selectively removed in $76 \%$ yield by treatment with five equivalents of $n$-BuLi and quenching with acid after 15 seconds (Scheme 2). After bridging of the last two hydroxyl groups the remaining two bromo atoms can be replaced by electrophiles via the dilithio compound resulting in compounds 8, which can also be used for coupling with other building blocks [7].

\section{Selective Functionalization of Calix[4]arenes}

In p-tert-butylcalix[4]arene $9 \mathrm{~b}$, which exists in a cone conformation as drawn, two very different reactive sites can be distinguished. The four hydroxyl groups together form 


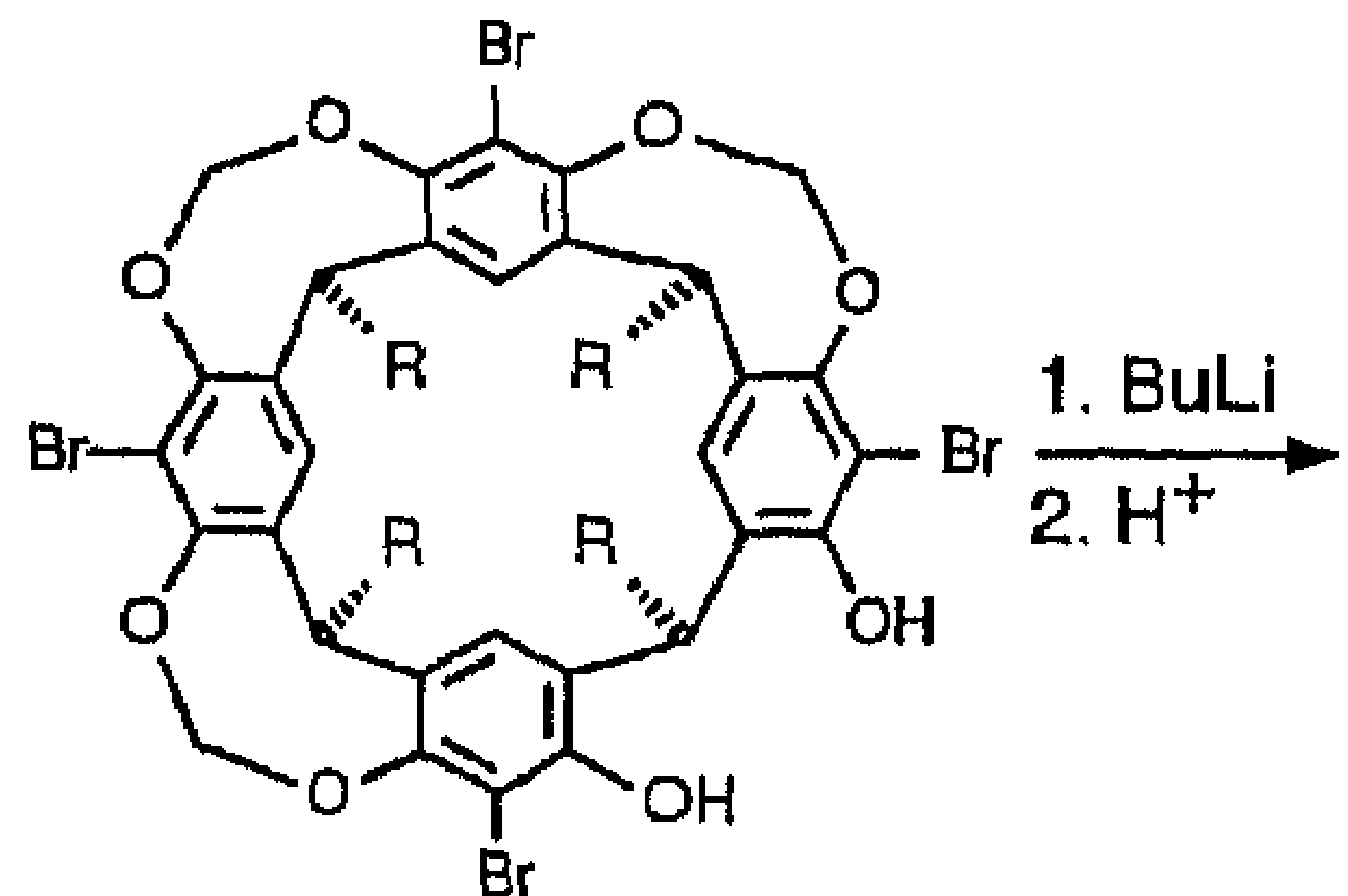

6

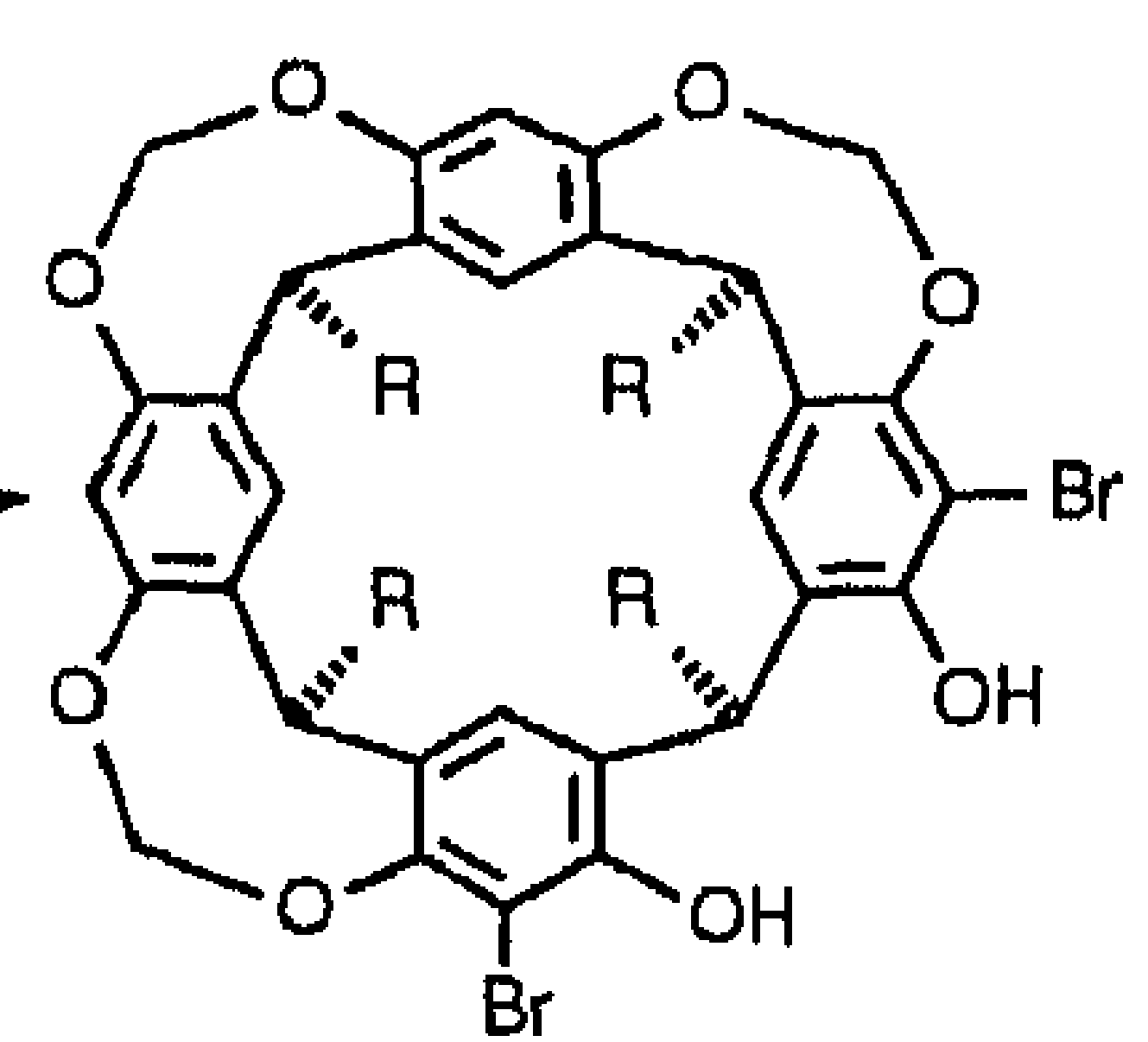

$7(76 \%)$

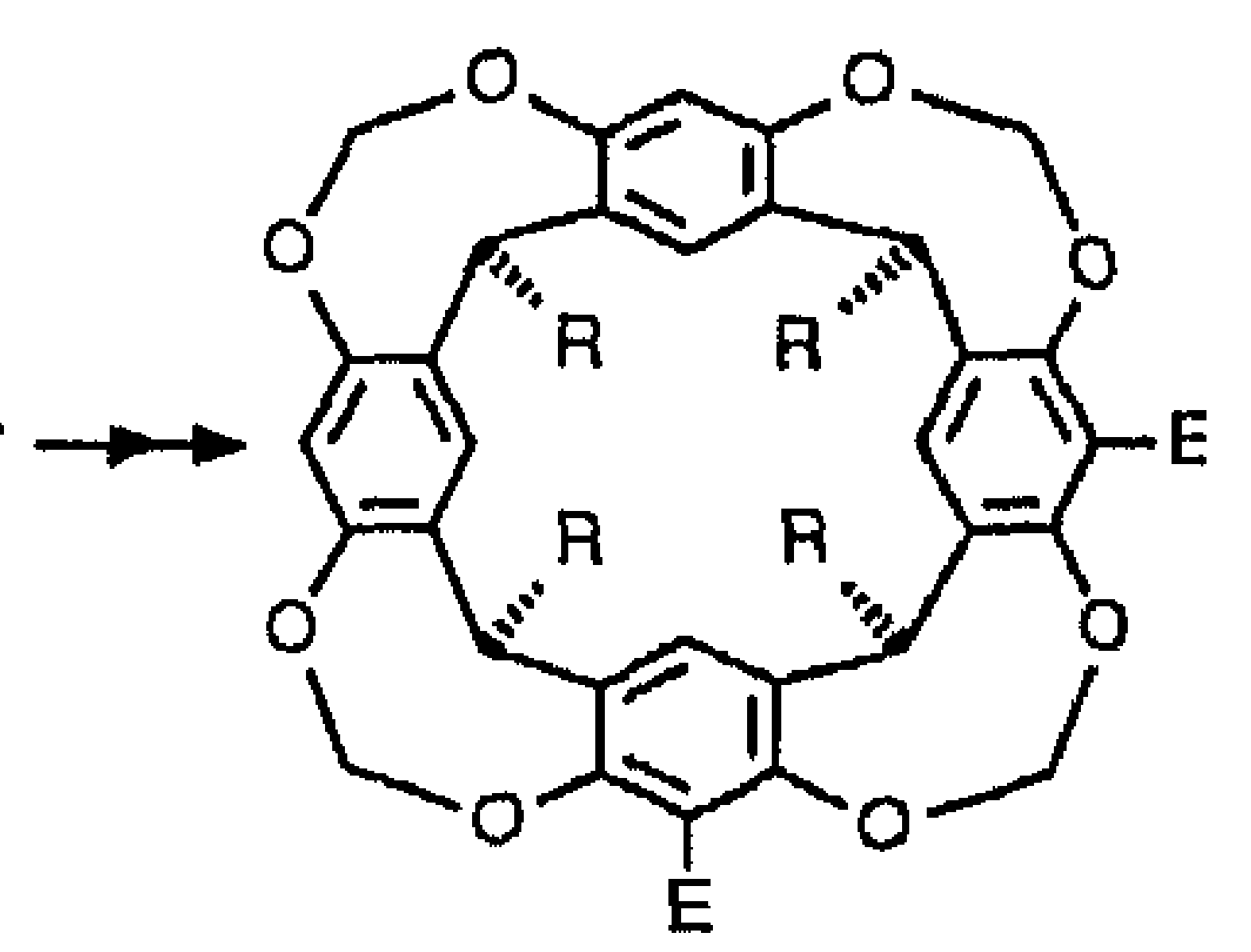

$8 \mathbf{E}=\mathrm{CN}>95 \%$ $8 b E=C O O M e \quad 60 \%$

Scheme 2

the lower rim of the calix[4]arene and the para-positions of the four phenol rings form the upper rim. We have been able to design new methods for the selective functionalization of both the lower and the upper rim of calix[4]arenes.

\subsection{SELECTIVE FUNCTIONALIZATION OF THE LOWER RIM}

4.1.1. Monoalkylation. Monoalkylated calix[4]arenes have been obtained by selective dealkylation of the corresponding dialkyl or tetraalkyl ethers with one or three equivalents of $\mathrm{Me}_{3} \mathrm{SiI}$, respectively [8]. We recently found that direct alkylation of calix[4]arene with excess of alkylating agent in the presence of 1.2 equivalents of a very weak base, $\mathrm{CsF}$ in $N, N$-dimethylformamide (DMF), is an attractive alternative (see Scheme 3) [9]. The use of 0.6 equivalents of $\mathrm{K}_{2} \mathrm{CO}_{3}$ in acetonitrile also afforded reasonable amounts of monoalkylated products, but 1,3-disubstituted products were always formed as side-products. The alkylations with weak base proceed via the monoanion of the calix[4]arene. The oxyanion is stabilized by two hydrogen bonds from neighboring phenolic groups. However, also the monoanion of the monoalkylated calix[4]arene can be stabilized by two hydrogen bonds and consequently there exists

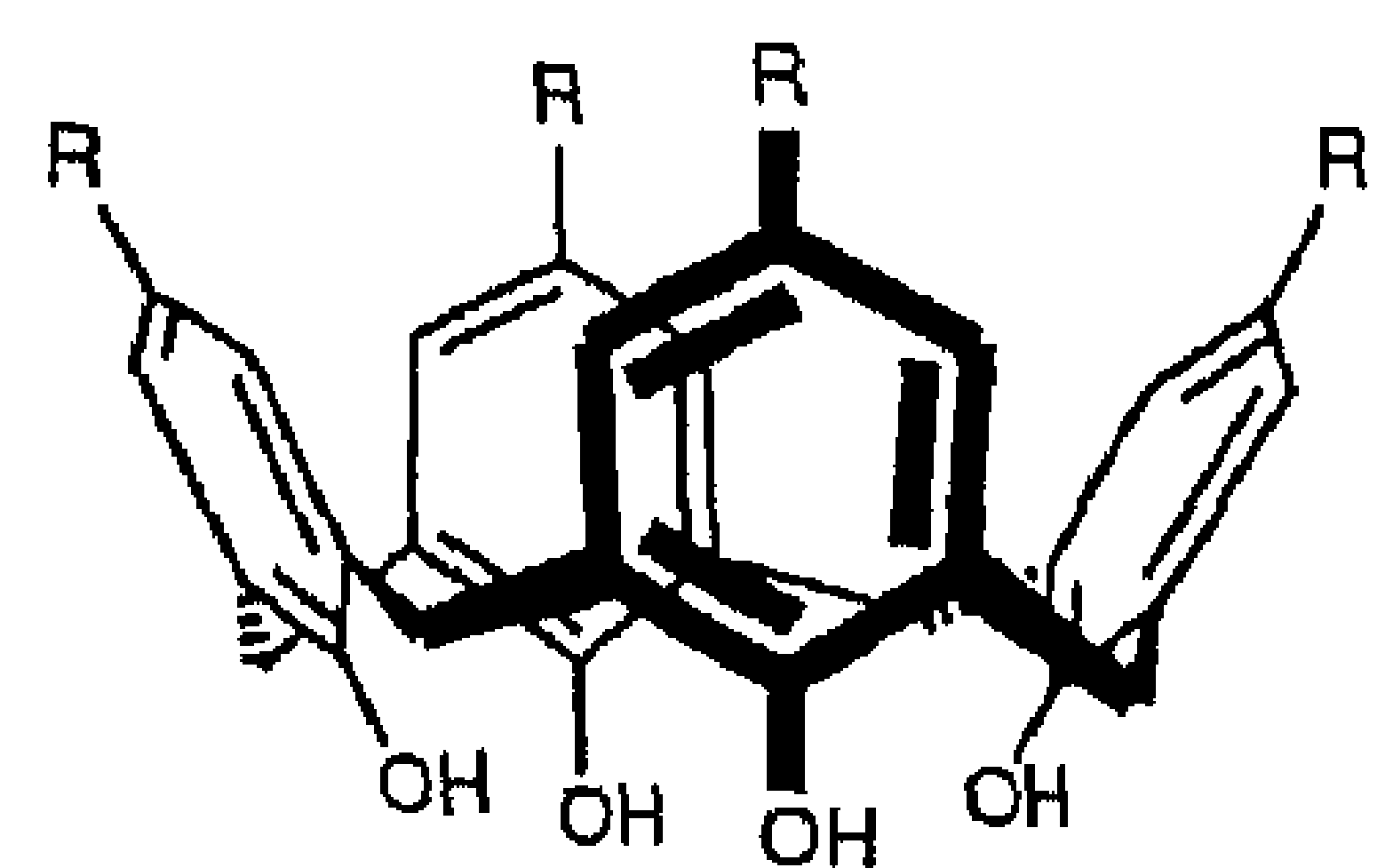

9 a $\mathrm{R}=\mathrm{H}$

b $\mathrm{A}=\underline{\mathrm{t}}-\mathrm{Bu}$
$1.2 \mathrm{eq}$ CsF excess $R_{1} X$

$\mathrm{DMF}, 40^{\circ} \mathrm{C}$

\section{Scheme 3}

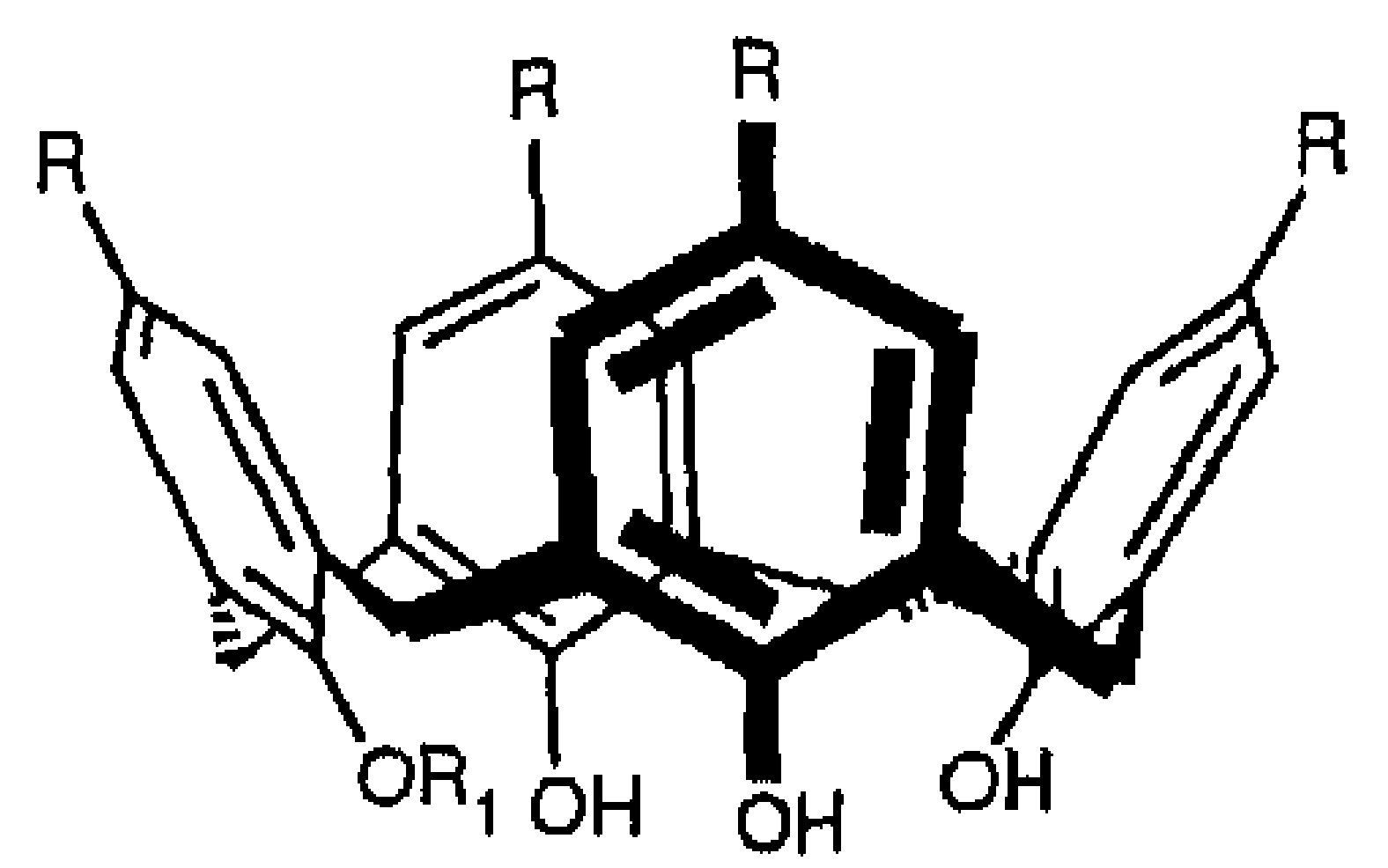

$10 R_{1}=\mathrm{Me}, \mathrm{Et}$, allyl, $\mathrm{CH}_{2} \mathrm{C}(\mathrm{O}) \mathrm{OEt}$ 
only a small difference in basicity and reactivity of these two monoanions. The use of a very weak base is necessary to distinguish between the two anions. Apparently, $\mathrm{K}_{2} \mathrm{CO}_{3}$ and $\mathrm{KHCO}_{3}$, which is formed during the reaction, are too strong bases to affect selective monoalkylation.

4.1.2. 1,3-Dialkylation. Calix[4]arenes can be alkylated selectively on two diametrically located phenol rings by reaction with two equivalents of an alkylating agent in the presence of one equivalent of $\mathrm{K}_{2} \mathrm{CO}_{3}[10,11]$. The yields are generally excellent and the products (11) exist in the cone conformation. This reaction is very selective because the monoanion of the 1,3-disubstituted calix[4]arene, from which further substitution would have to take place, cannot be stabilized by hydrogen bonds, or only a very weak one from the diametrically positioned phenol ring. Thus, this anion is not formed in any significant amounts under these reaction conditions with weak base.
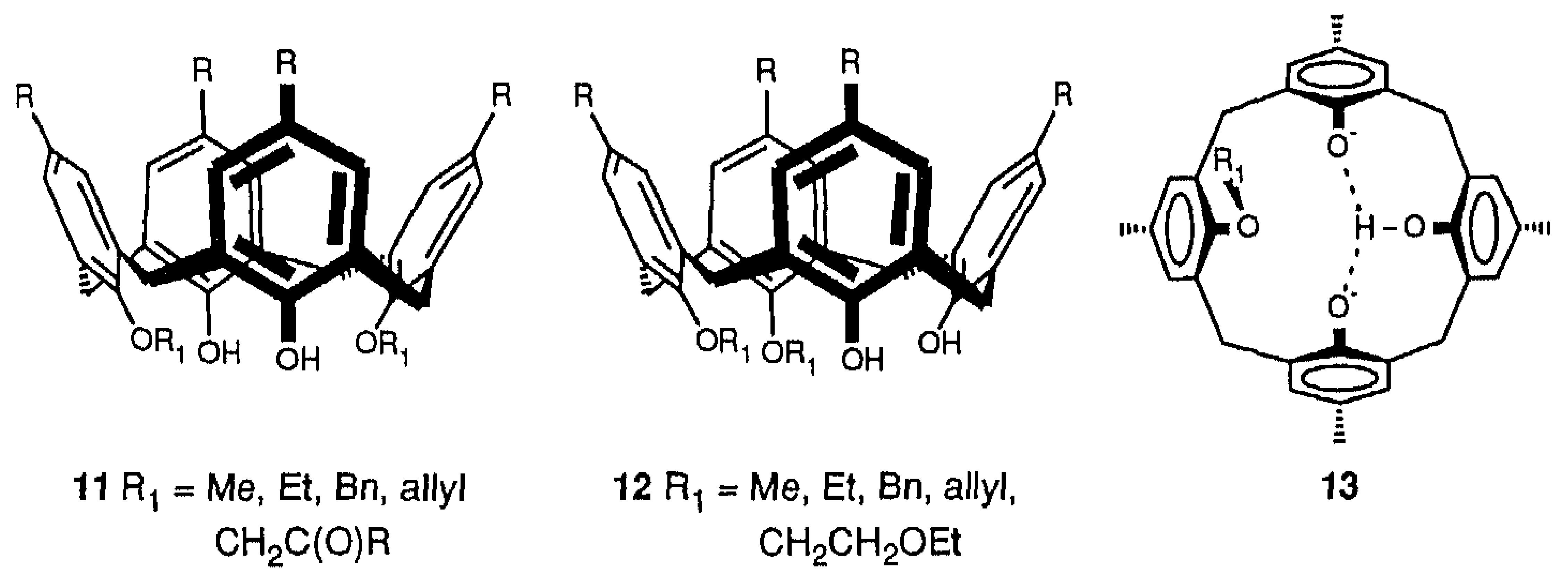

13

4.1.3. 1,2-Dialkylation. The use of strong base instead of weak base completely alters the selectivity of the alkylation reaction. Reaction of unsubstituted calix[4]arenes with excess of $\mathrm{NaH}$ in $\mathrm{N}, \mathrm{N}$-dimethylformamide or acetonitrile and 2.2 equivalents of alkylating agent yields the 1,2-disubstituted calix[4]arenes $\mathbf{1 2}$ in the cone conformation in 15-55\% yield [12]. An important side-product is the tetrasubstituted calix[4]arene in the cone conformation, beside starting material. Under the strongly basic conditions of this reaction the calix[4]arene is multideprotonated. The formation of the 1,2-disubstituted calix[4]arenes can be rationalized by assuming that the dianion of the monoalkylated calix[4]arene (13) is an intermediate. This will have the structure as shown because of minimization of repulsion between the two oxyanions and the stabilizing effect of the hydrogen bond of the hydroxyl group in the middle. Apparently the calix[4]arene is not completely deprotonated under these conditions. 
4.1.4. Replacement of the Phenolic OH Groups. Recently the synthesis of completely dehydroxylated calix[4]arene 14d by reductive cleavage ( $\mathrm{K}$ in liquid ammonia) of the tetrakis(diethyl phosphate) ester of $p$-tert-butylcalix[4]arene $9 \mathrm{~b}$ has been reported [13]. Starting from the 1,3-di- and tetraesters of $9 \mathbf{b}$ we could isolate the partially dehydroxylated calix[4]arenes 14a-c [14].

The hydroxyl groups can be replaced by thiol groups via the Newman-Kwart rearrangement of the corresponding $O$-dimethylthiocarbamates. The dithiols $15 \mathrm{~b}$ and $15 \mathrm{c}$ were synthesized by reduction of the $S$-dimethylthiocarbamates that were obtained after the Newman-Kwart rearrangement of the $O$-dimethylthiocarbamates of $15 \mathrm{a}$ and 14b [14].
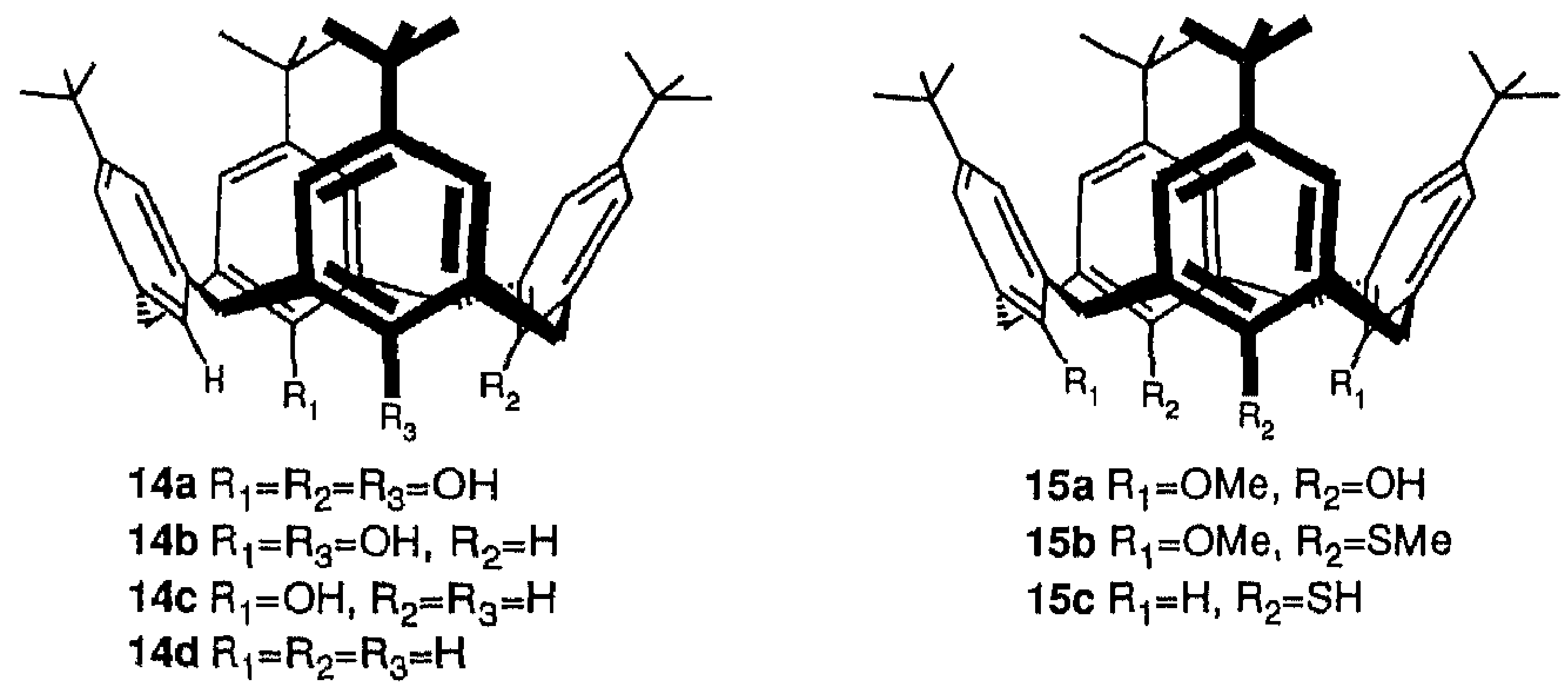

\subsection{CONFORMATIONS OF TETRASUBSTITUTED CALIX[4]ARENES}

The calix[4]arenes discussed so far all exist in the cone conformation because of the syn-orientation of the substituents and the presence of hydroxyl groups that stabilize the cone conformation by the formation of hydrogen bonds. However, beside the cone a calix[4]arene can adopt three other conformations, viz. the partial cone, the 1,2-alternate and the 1,3-alternate (see Scheme 4). In tetrasubstituted calix[4]arenes, in which no free hydroxyl groups are present, all these four conformations can in principal be formed.

4.2.1. Flexible Calix[4]arenes. The tetramethyl ether of p-tert-butylcalix[4]arene (16), which is a mobile compound, was first synthesized by Gutsche and coworkers [15]. They concluded from the low-temperature ${ }^{1} \mathrm{H}$ NMR spectrum that it consists as a mixture of two partial cone conformations, one in which the methyl group of the 


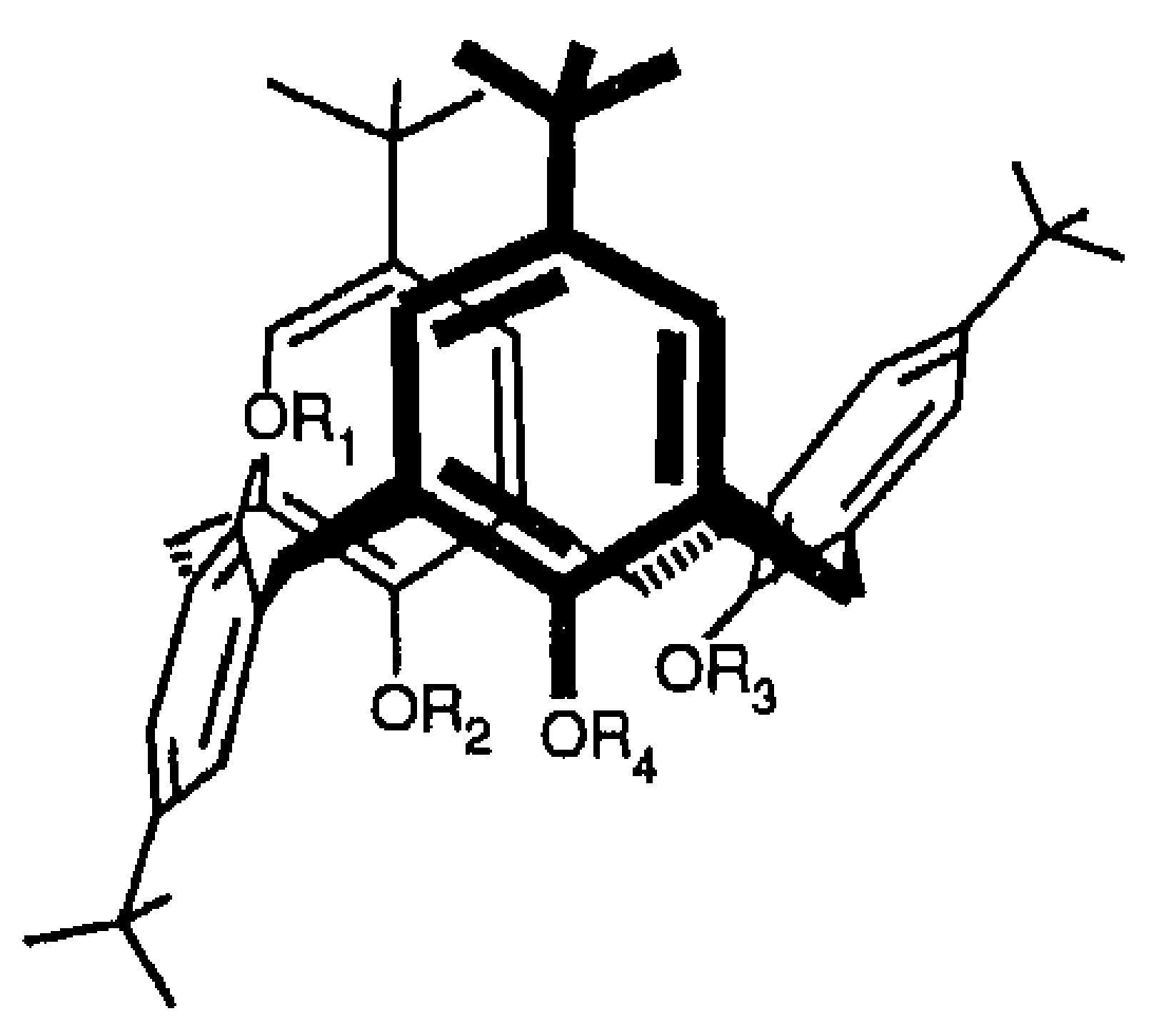

$16 \quad R_{1}=R_{2}=R_{3}=R_{4}=M e$

17a $R_{1}=R_{2}=M e, R_{3}=R_{4}=E t$

$17 b \mathrm{R}_{1}=\mathrm{R}_{3}=\mathrm{Me}, \mathrm{R}_{2}=\mathrm{R}_{4}=\mathrm{Et}$

$17 \mathrm{c} R_{2}=R_{3}=\mathrm{Me}, R_{1}=R_{4}=E t$

$17 \mathrm{~d} \mathrm{R}_{2}=\mathrm{R}_{4}=\mathrm{Me}, \mathrm{R}_{1}=\mathrm{R}_{3}=\mathrm{Et}$

$18 R_{1}=R_{2}=R_{3}=R_{4}=E t$

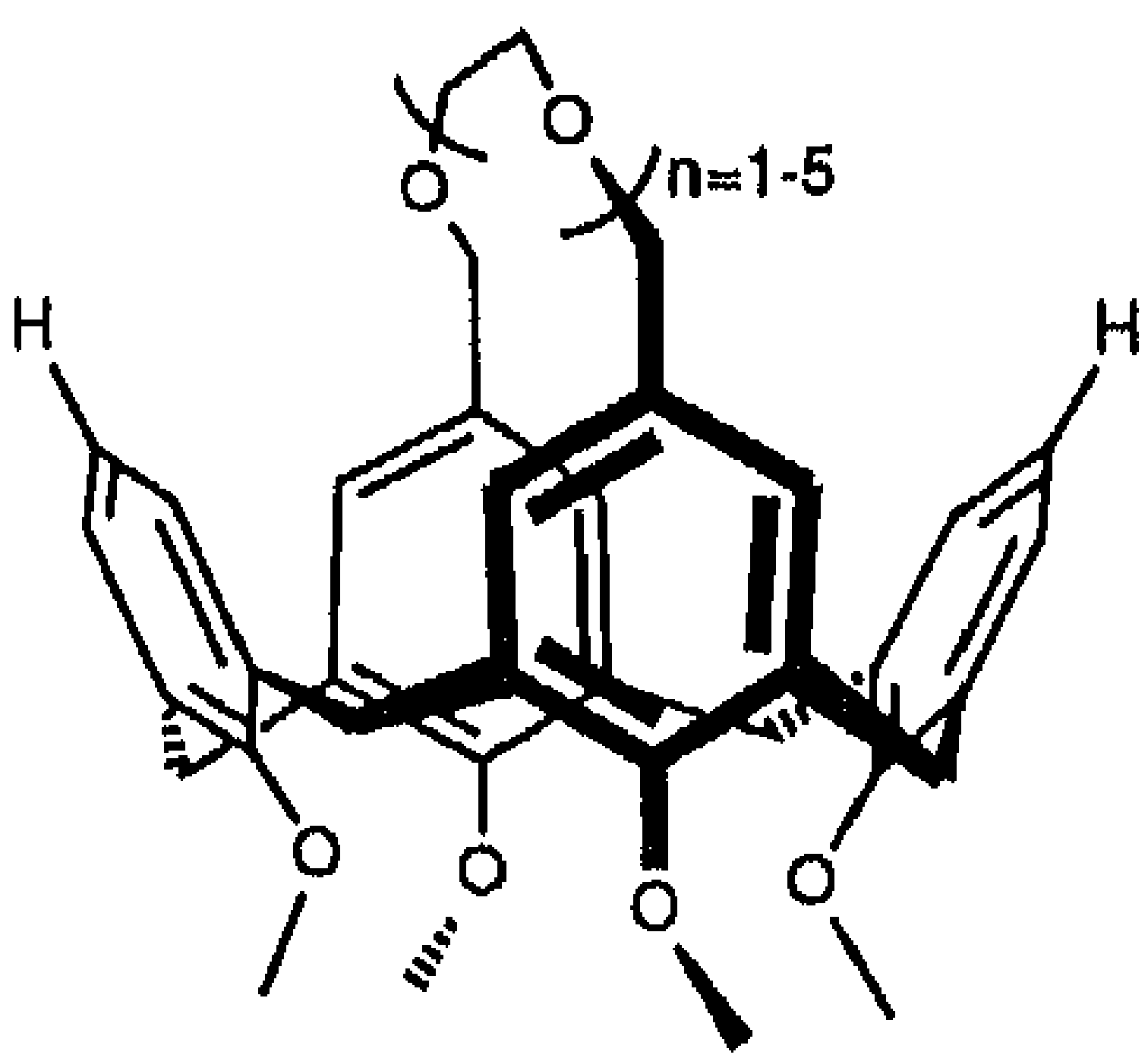

19

rotated aromatic ring points outwards and one in which this methyl group points into the cavity. Reinvestigation of the ${ }^{1} \mathrm{H}$ NMR spectrum showed that compound 16 exists as a mixture of all four conformations (see Table 1) [16]. In a 2D EXSY spectrum at the same low temperature cross peaks due to chemical exchange were present between signals of the partial cone and the cone, and of the partial cone and the 1,3-alternate, which indicates that these conformations interconvert. Strange enough no crosspeaks corresponding with signals of the 1,2-alternate were present. In the ${ }^{1} \mathrm{H}$ NMR spectrum at room temperature the signals of the 1,2-alternate conformation are still sharp, whereas the other signals have broadened, and only at higher temperature also the signals of the 1,2-alternate broaden and coalesce with the other signals. This indicates that the interconversion involving the 1,2-alternate is much slower than the interconversion between cone, partial cone and 1,3-alternate. The 1,2-alternate is the kinetically most stable conformation. The complete interconversion process is depicted in Scheme 4.

In order to obtain more information about the factors that influence the ratios of the conformations and the interconversion process we investigated the properties of partially fixed calix[4]arenes. Using different methods for selective functionalization, we synthesized a series of mixed diethyldimethyl ethers (17), that are partially rigidified because of the presence of the ethoxy groups [16]. The partial fixation precludes one or two of the conformations and in this way also certain pathways for interconversion are excluded. Table 1 shows the ratios of conformations of the four 


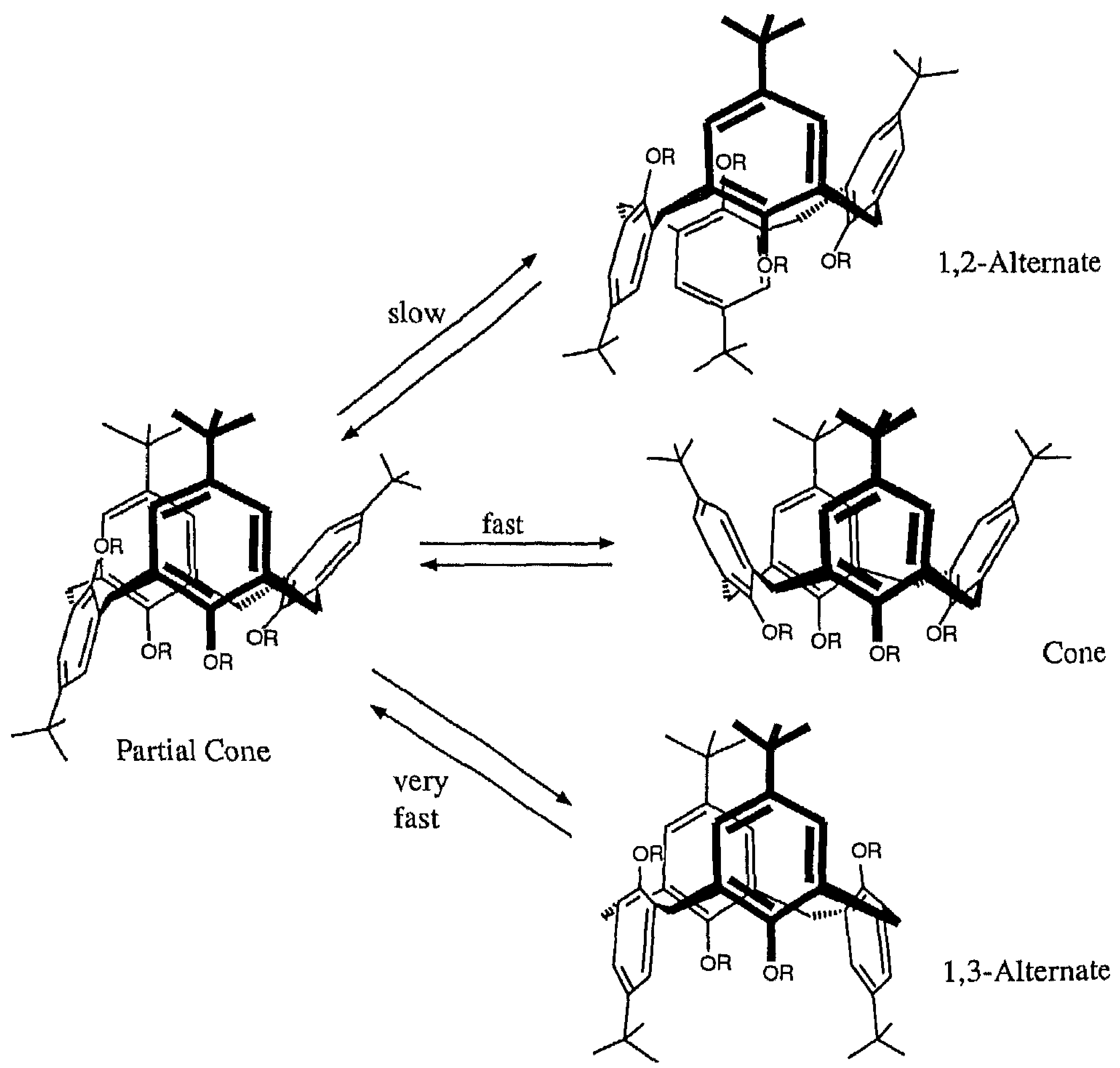

Scheme 4

different diethyldimethyl ethers. In compound $\mathbf{1 7 b}$ the 1,2-alternate is precluded and the ${ }^{1} \mathrm{H}$ NMR spectrum at room temperature shows only broad peaks, indicating a fast interconversion between cone, partial cone and 1,3-alternate. For compounds 17a and 17c sharp peaks of the 1,2-alternate are visible beside broad signals of the other conformations, showing that the 1,2-alternate is also in these compounds a kinetically stable conformation. When both the cone and the 1,3-alternate are precluded as in compound 17d only sharp peaks appear in the ${ }^{1} \mathrm{H}$ NMR spectrum because the two fast interconversion pathways are precluded. Interestingly, the 1,2-alternate is also thermo- 
Table 1. Relative Equilibrium Concentrations of the Tetramethyl, Diethyldimethyl and Tetraethyl Ethers of $p$-tert-ButylCalix[4]arene. (Measured in $\mathrm{CDCl}_{3}$ at $-30^{\circ} \mathrm{C}$, in \%.)

\begin{tabular}{|l|cccc|}
\hline & cone & partial cone & 1,2-alternate & 1,3-alternate \\
\hline $\mathbf{1 6}$ & 4 & 85 & 8 & 3 \\
$\mathbf{1 7 a}$ & $<5^{\mathrm{a}}$ & 76 & 24 & $--\mathrm{b}$ \\
$\mathbf{1 7 b}$ & 20 & 80 & $--^{\mathrm{b}}$ & $<5^{\mathrm{a}}$ \\
$\mathbf{1 7 c}$ & $--\mathrm{b}$ & 64 & 25 & 11 \\
$\mathbf{1 7 d}^{\mathrm{c}}$ & $--\mathrm{b}$ & 35 & 65 & $--\mathrm{b}$ \\
$\mathbf{1 8}^{\mathrm{d}}$ & 7 & 47 & 43 & 3 \\
\hline
\end{tabular}

a This conformation could not be ruled out because of the low resolution of the ${ }^{1}$ H NMR spectrum. ${ }^{b}$ Precluded conformation for this compound.

${ }^{\circ}$ Measured at room temperature. ${ }^{d}$ Measured in $\mathrm{CDCl}_{2} \mathrm{CDCl}_{2}$ at $132^{\circ} \mathrm{C}$.

dynamically the most stable conformation for this compound.

Another way of rigidifying the tetramethyl ether is by bridging the upper rim of the calix[4]arene. We prepared compounds 19 from the selectively functionalized 1,3-p-diacid chloride of tetramethoxycalix[4]arene and the appropriate polyethylene glycol [17]. As for the comparable compound $\mathbf{1 7 b}$ only the cone and the partial cone conformations could be observed, although the interconversion process involving the 1,3-alternate also takes place. A kinetic investigation of the interconversion process of compounds $19(n=1$ and $n=2)$ by quantitative 2D EXSY NMR spectroscopy showed that the interconversion via the 1,3-alternate is more than a factor of 10 faster than via the cone.

Even the tetraethyl ether of $p$-tert-butylcalix[4]arene (18) is flexible, but only at temperatures higher than $100^{\circ} \mathrm{C}$. Shinkai and coworkers have reported that the partial cone conformation of this compound slowly isomerizes to the 1,2-alternate, resulting in a nearly $1: 1$ mixture of partial cone and 1,2-alternate [18]. With the above results in mind we reinvestigated this system and we could show that also this compound adopts all four conformations (see Table 1) [16]. A kinetic investigation of the conversion of the partial cone to the other three conformations confirmed the relative rates of the three processes.

4.2.2. Conformationally Fixed Calix[4]arenes. For calix[4]arenes with four substituents larger than the ethoxy group the interconversion is completely blocked [18]. Therefore, the conformation of these compounds is determined during their 
synthesis and depends on kinetic factors. Control of the conformation of the final tetrasubstituted calix[4]arenes would allow for the synthesis of four different building blocks, namely the four conformations.

We have investigated the influence of the strong base and the solvent on the conformational outcome of the tetraethylation of $p$-tert-butylcalix[4]arene $9 \mathrm{~b}$ (see Table 2) [12]. The use of $\mathrm{NaH}$ in $N, N$-dimethylformamide (DMF) or acetonitrile at room temperature exclusively leads to the tetraethylated calix[4]arene in the cone conformation in good yield. Also in reactions with other electrophiles exclusively the cone conformation is obtained [19]. The previously discussed 1,2-dialkylated calix[4]arenes are intermediates in these reactions [12]. When $\mathrm{KH}$ or potassium tert-butoxide $(\mathrm{KO} \mathrm{tBu})$ was used instead of $\mathrm{NaH}$ a mixture of all four conformations was obtained with the partial cone as the major product.

Shinkai and coworkers have reported that the tetra-n-propylation of $9 \mathrm{~b}$ with $\mathrm{Cs}_{2} \mathrm{CO}_{3}$ in DMF yields a mixture of partial cone, 1,2-alternate and 1,3-alternate conformations [18b]. Recently we found that alkylation of calix[4]arenes with other para-substituents under the same conditions yields mainly the 1,3-alternate conformation of the tetraalkylated calix[4]arenes [20].

The 1,2-alternate conformation cannot yet be obtained from direct alkylation reactions in attractive yields. We were able to show that ethylation of the anti-1,3diethyl ether of $\mathbf{9 b}$ with $\mathrm{KOtBu}$ in tetrahydrofuran afforded the 1,2-alternate conformation of the tetraethyl ether in $64 \%$ yield [16]. Apparently, the anti-1,3-diethyl ether is not formed in large quantities in the reaction starting from p-tert-butylcalix[4]arene $9 \mathrm{~b}$ under the same conditions.

Table 2. Results of Tetraethylation of p-tert-Butylcalix[4]arene (EtI, RT, $24 \mathrm{~h}$ ).

\begin{tabular}{|ll|rccc|}
\hline \multicolumn{2}{|l|}{$\begin{array}{l}\text { Reaction conditions } \\
\text { base }\end{array}$} & \multicolumn{4}{|c|}{ Relative yields of conformation (\%) } \\
cone & partial cone & 1,2-alternate & 1,3-alternate \\
\hline $\mathrm{NaH}$ & $\mathrm{DMF}$ & 100 & $\mathrm{a}$ & $\mathrm{a}$ & $\mathrm{a}$ \\
$\mathrm{NaH}$ & $\mathrm{MeCN}$ & 100 & $\mathrm{a}$ & $\mathrm{a}$ & $\mathrm{a}$ \\
$\mathrm{NaH}$ & THF/DMF 10:1 & 62 & 28 & 10 & $\mathrm{a}$ \\
$\mathrm{NaH}$ & $\mathrm{THF}$ & $\mathrm{b}$ & $\mathrm{b}$ & $\mathrm{b}$ & $\mathrm{b}$ \\
$\mathrm{KH}$ & $\mathrm{DMF}$ & 2 & 64 & 17 & 17 \\
$\mathrm{KH}$ & THF & $\mathrm{a}$ & 64 & 5 & 31 \\
$\mathrm{KOtBu}$ & $\mathrm{MeCN}$ & 5 & 84 & 2 & 9 \\
$\mathrm{KOtBu}$ & $\mathrm{THF}$ & $\mathrm{a}$ & 77 & $\mathrm{a}$ & 23 \\
\hline
\end{tabular}

${ }^{a}$ Not detected in the ${ }^{1} \mathrm{H}$ NMR spectrum. ${ }^{b}$ No product had been formed after $24 \mathrm{~h}$. 
Except for two examples of mono-p-allylcalix[4]arenes [21] functionalization of the upper rim of calix[4]arenes has only been performed at all four para-positions simultaneously. We realized that the selectively lower rim-functionalized calix[4]arenes can be useful starting materials for the selective introduction of functional groups at the upper rim, and we have developed several strategies to prove this.

4.3.1. Transfer of Functionality. The selective functionalization of the lower rim allows for the synthesis of mixed alkylallyl ethers that can be subjected to a $p$-Claisen rearrangement [10]. In this way compounds of general structure 20a, in which the selectivity has been transferred from the lower rim to the upper rim, were obtained in good yields. The allyl group can easily be transformed to other functional groups $\left(\mathrm{CH}_{2} \mathrm{X}, \mathrm{CH}_{2}=\mathrm{O}, \mathrm{COOH}\right)$.

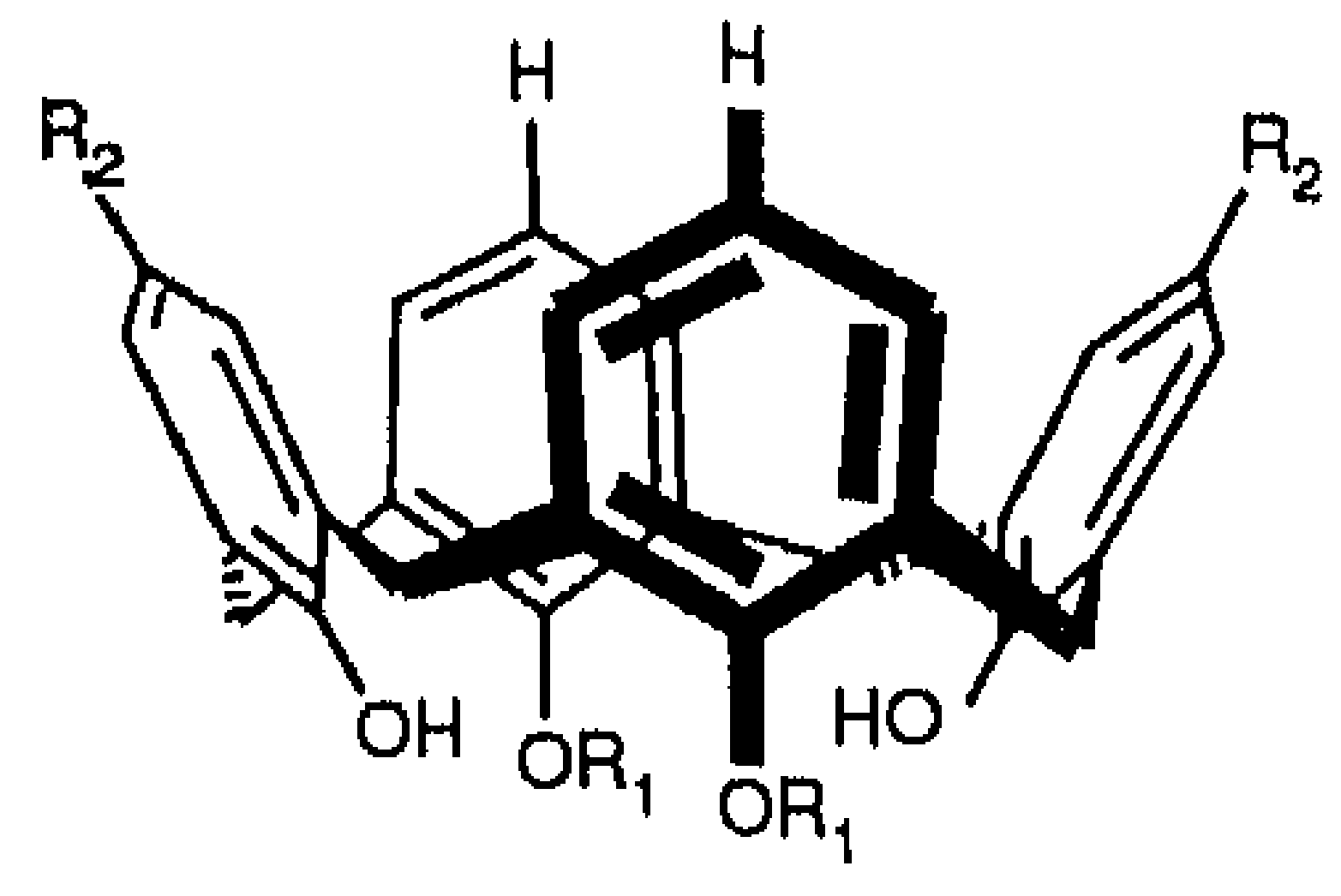

20a $R_{1}=$ alkyl, $R_{2}=$ allyl $20 b R_{1}=$ alkyl, $R_{2}=E$

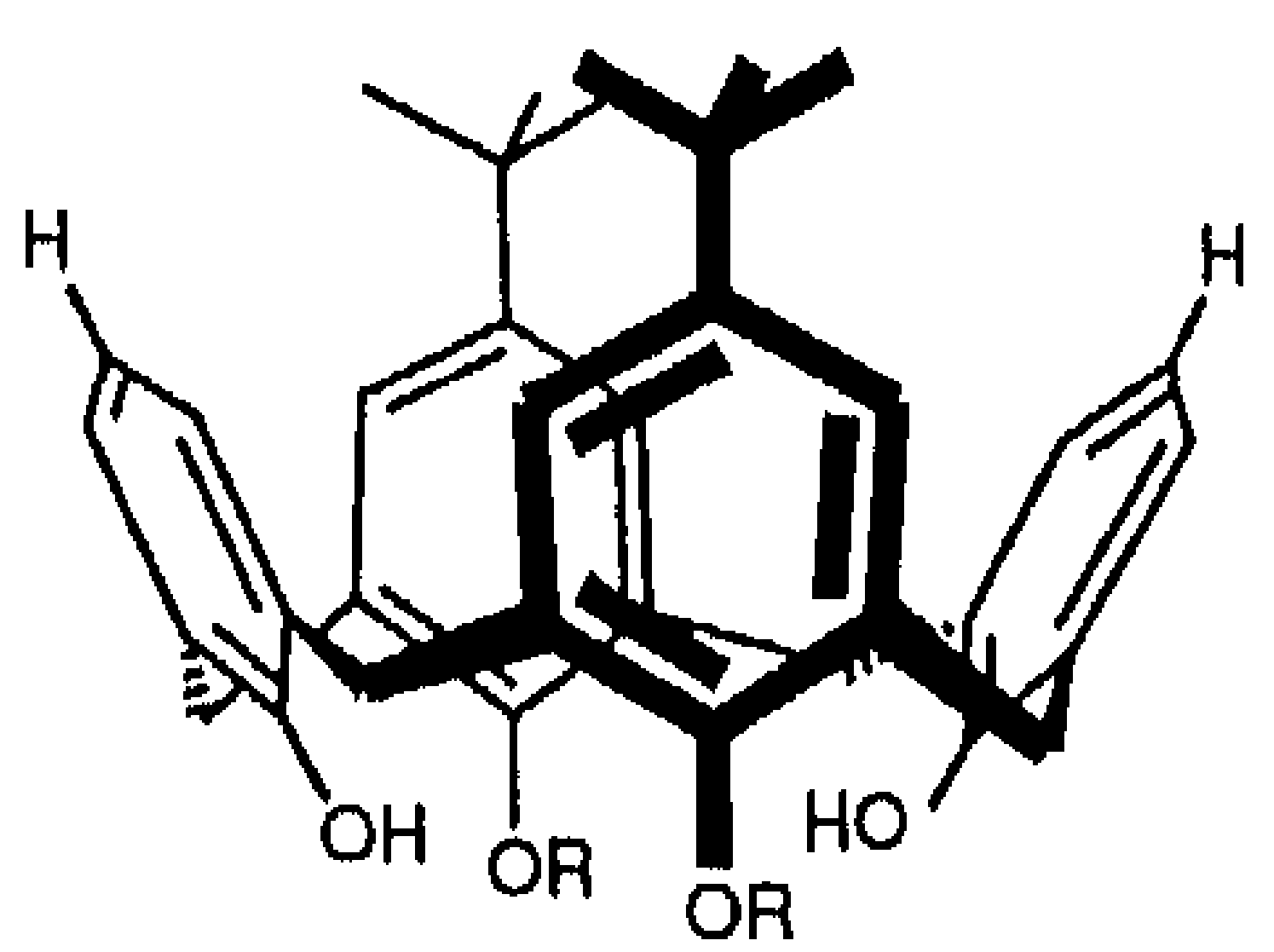

$21 \mathrm{R}=\mathrm{alkyl}$

4.3.2. Direct Substitution. A second method for the selective functionalization of the upper rim takes advantage of the fact that electrophilic aromatic substitutions are faster on phenols than on alkylated phenols. Starting with dialkylated calix[4]arenes a wide variety of electrophiles ( $\left.\mathrm{Br}, \mathrm{NO}_{2}, \mathrm{CH}_{2}=\mathrm{O}, \mathrm{HgOTFA}\right)$ can be introduced selectively on the para-positions of the phenol rings in yields $>80 \%$ (compounds 20b) [10].

4.3.3. Selective Removal of tert-Butyl Groups. The difference in reactivity between phenols and alkylated phenols can also be exploited for the selective removal of two tert-butyl groups from dialkoxy-p-tert-butylcalix[4]arenes [10]. This leads to calix[4]arenes 21 in which the two alkoxy-substituted rings remain protected, while the two phenol rings can be further functionalized on the para-positions by the methods described above. 
4.3.4. Selective Nitration of Tetrasubstituted Calix[4]arenes. The presence of a selectively functionalized lower rim is not an absolute prerequisite for selective functionalization of the upper rim. We found that the reaction of the tetra- $n$-propyl ether of de-tert-butylated calix[4]arene $9 \mathrm{a}$ in the cone conformation with 15 equivalents of $65 \% \mathrm{HNO}_{3}$ in $\mathrm{CH}_{2} \mathrm{Cl}_{2}$ for 30 minutes gave the mononitrated calix[4]arene 22a in $55 \%$ yield [22]. When the reaction time is prolonged to $2.5-5$ hours and a little acetic acid is added a mixture of nitrated calix[4]arenes is obtained from which the 1,2-dinitro (22c) and the 1,3-dinitro compounds (22b) could be isolated in 10 and $30 \%$, respectively. The reaction of the tetrakis(ethoxyethyl) ether with acetyl nitrate in $\mathrm{CH}_{2} \mathrm{Cl}_{2}$ at room temperature afforded $30-40 \%$ of the 1,3-dinitrated product together with $20 \%$ of the mononitro compound [23]. The 1,2-dinitrated product was not observed in this reaction.

We recently discovered that the tert-butyl groups of tetrasubstituted calix[4]arenes can also be replaced directly by nitro groups (ipso-nitration) [19]. When this reaction is performed with $100 \% \mathrm{HNO}_{3}$ in $\mathrm{CH}_{2} \mathrm{Cl}_{2} / \mathrm{AcOH}$ tetranitrocalix[4]arenes (e.g. 22d) were obtained, but under milder conditions $\left(65 \% \mathrm{HNO}_{3}\right)$ each of the four partially nitrated calix[4]arenes was formed. The tetranitration not only works for tetrasubstituted p-tert-butylcalix[4]arenes in the cone conformation, but also for the partial cone and the 1,3-alternate conformations (compounds 23 and 24) [22].

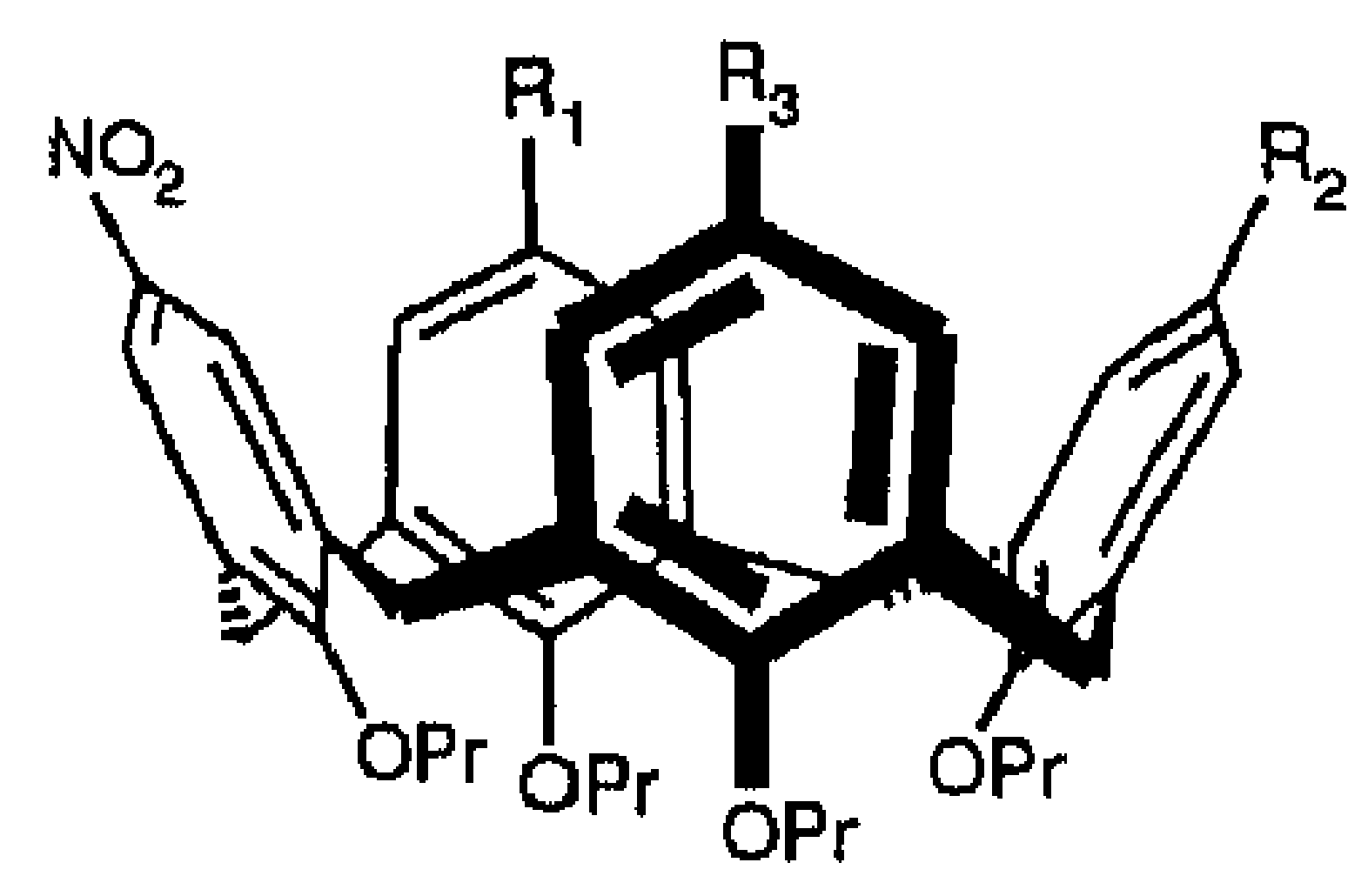

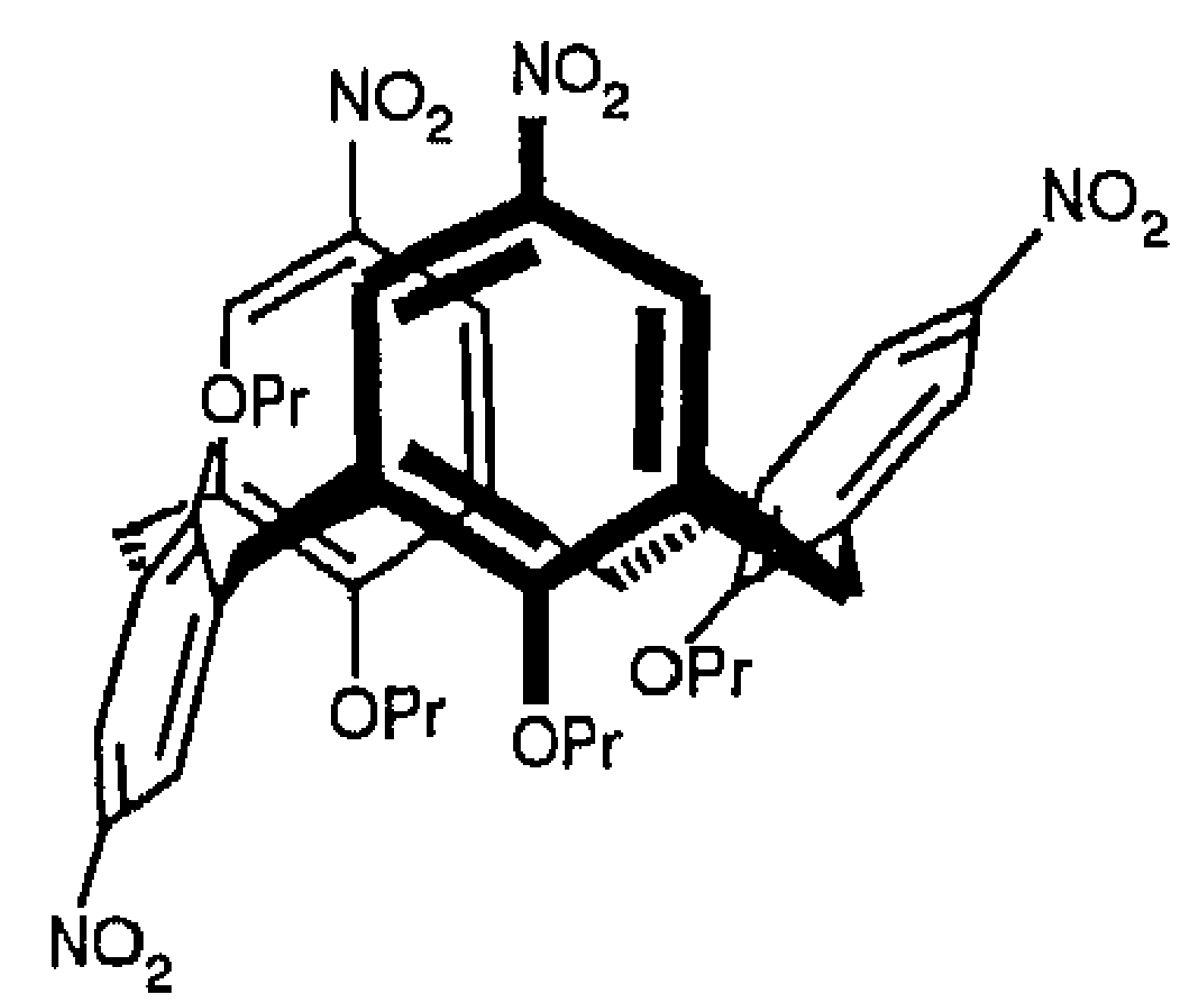

23

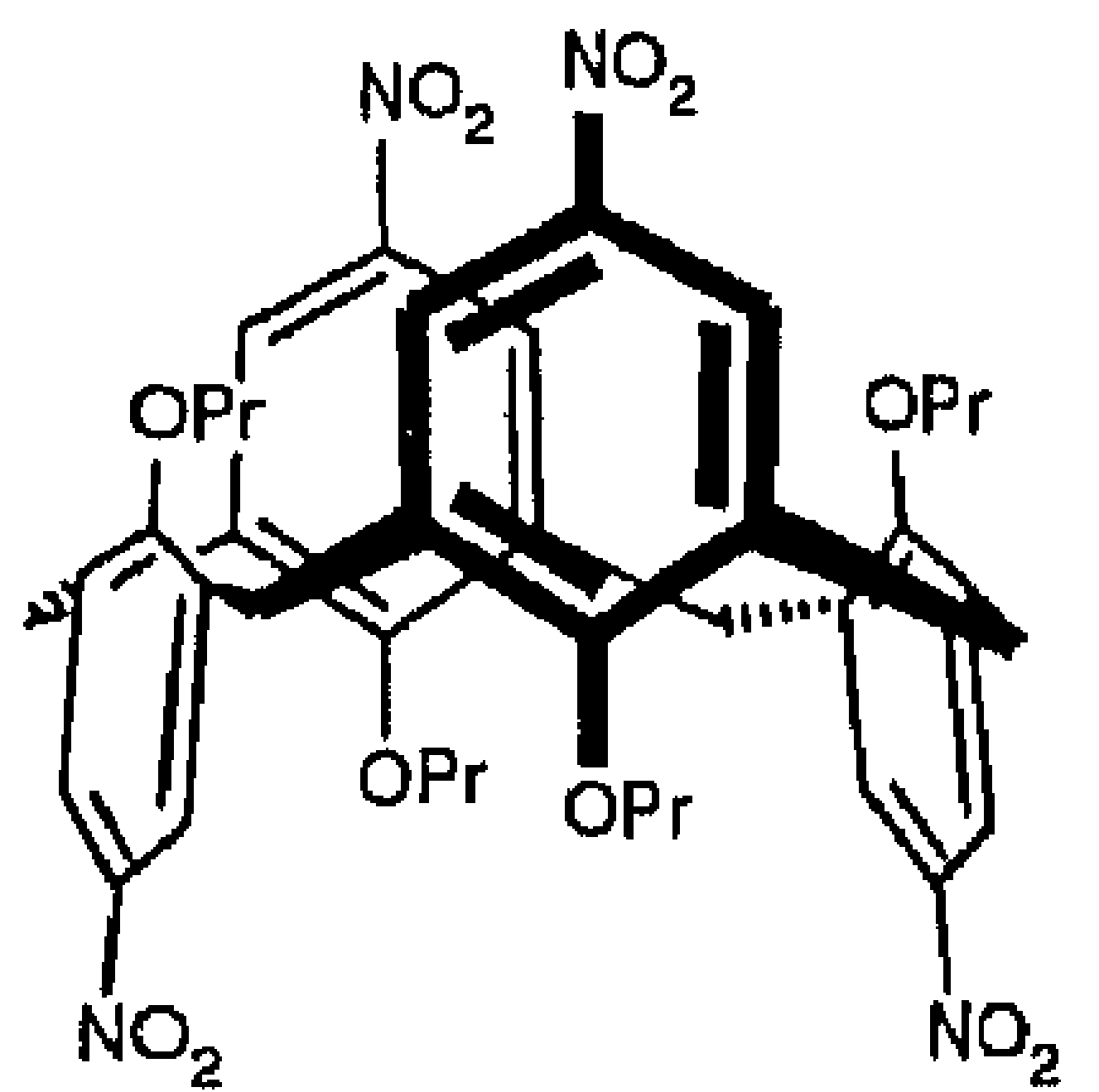

24

$22 b R_{1}=R_{3}=H, R_{2}=N O_{2}$

22c $\mathrm{R}_{2}=\mathrm{R}_{3}=\mathrm{H}, \mathrm{R}_{1}=\mathrm{NO}_{2}$

22d $R_{1}=R_{2}=R_{3}=\mathrm{NO}_{2}$ 


\section{Combination of Calix[4]arenes with Other Building Blocks}

Although the chemistry of calix[4]arenes is very interesting and (selectively) functionalized calix[4]arenes can have very useful properties, as was demonstrated above, the full potential of calix[4]arenes becomes apparent in their combinations with other building blocks. We will discuss a number of very successful compounds that are being used for different applications.

\subsection{CALIXCROWN ETHERS}

The reaction of calix[4]arene $9 \mathrm{~b}$ with tetraethylene glycol ditosylate gave the calixcrown ether 25 in $53 \%$ yield [24]. Subsequent alkylation afforded the 2,4-dialkylated calixcrowns 26 in mixtures of the cone, the partial cone and in some cases the 1,3-alternate conformations, except for the dimethyl ether 26a, which is flexible and adopts the cone conformation. These alkylated calixcrown ethers form complexes with alkali metal ions and all of them are selective for $\mathrm{K}^{+}$. The partial cone is not only the best conformation for complexation, which was nicely illustrated by compound 26a, which changed from a cone to a partial cone conformation upon complexation of a cation, but also shows the highest selectivity for $\mathrm{K}^{+}$. The dimethyl ether has been applied in a $\mathrm{K}^{+}$-selective electrode based on ISFET-technology [25] and in supported liquid membranes that are used for the selective transport of $\mathrm{K}^{+}[26]$.
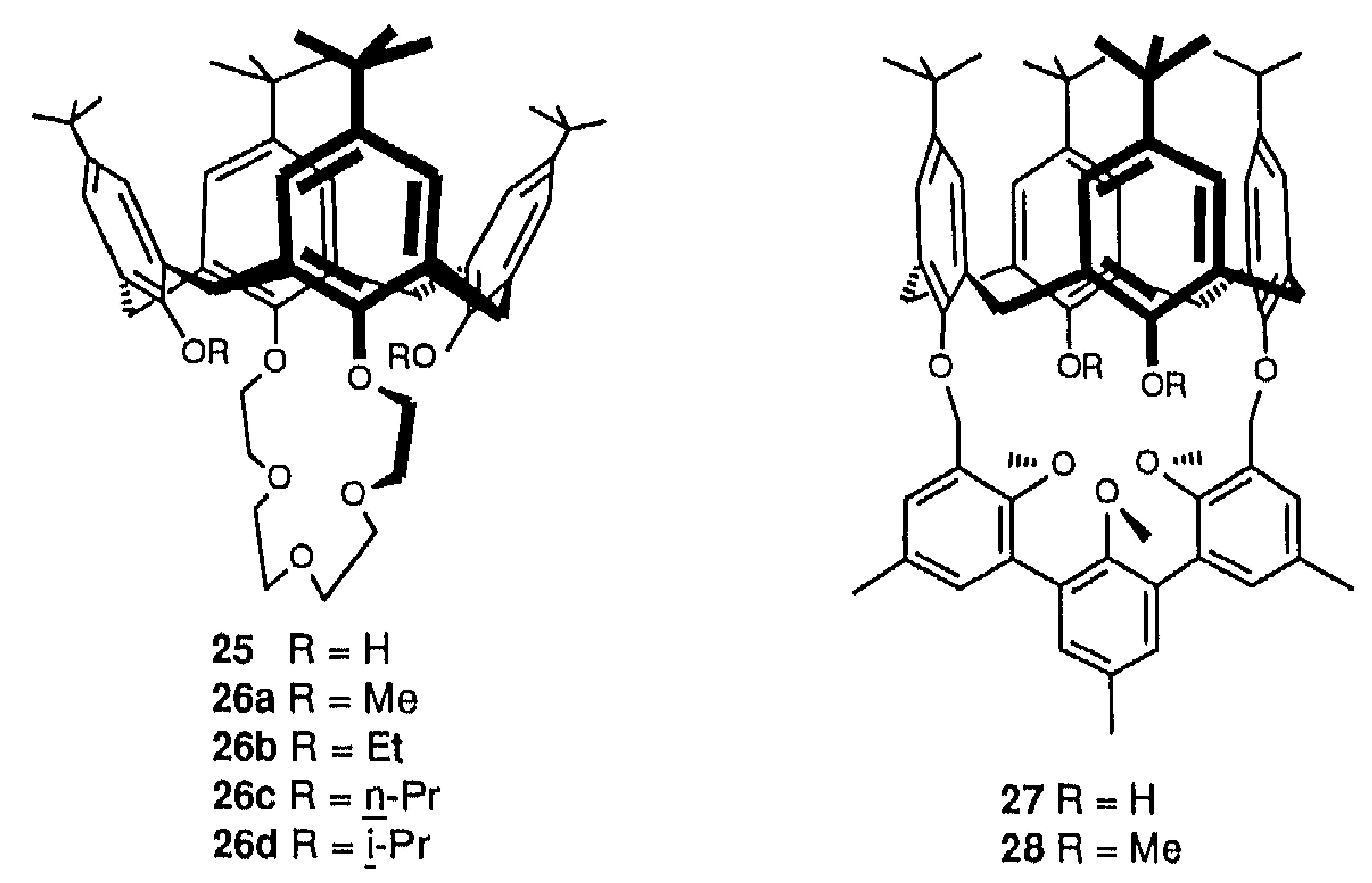


\subsection{CALIXSPHERANDS}

A few years ago the synthesis of a new type of molecules, the spherands, has been reported that form complexes with $\mathrm{Li}^{+}$and $\mathrm{Na}^{+}$that are not only thermodynamically but also kinetically very stable [27]. Combination of the 1,3-dimethyl ether of p-tert-butylcalix[4]arene with half a spherand molecule afforded the calixspherand 28 as its $\mathrm{Na}^{+}$complex in $23 \%$ yield [28]. The complexes of 28 with $\mathrm{Na}^{+}$and $\mathrm{K}^{+}$are kinetically very stable in $\mathrm{CDCl}_{3}$ saturated with $\mathrm{D}_{2} \mathrm{O}$, and have half-lives of 3.7 and 2.2 years. The conformation of the calix[4]arene moiety in these complexes is a "flattened" partial cone as in the complexes of the calixcrown ether 26a. Only recently we were able to prove that in the free ligand the calix[4]arene moiety adopts a cone conformation in complete analogy with compound 26a [29].

Currently we are trying to increase the kinetic stability of the $\mathrm{Rb}^{+}$complex, which has a half-life of only 2.8 hours, by introducing more bulky groups on the 2 - and 4-positions of the calix[4]arene, so that it can be used in organ imaging. Furthermore it is necessary to have a functional group in the calixspherand with which the calixspherand can be attached to an organ-specific compound (e.g. a peptide). For both purposes we employ a new strategy in which first the (functionalized) hemispherand

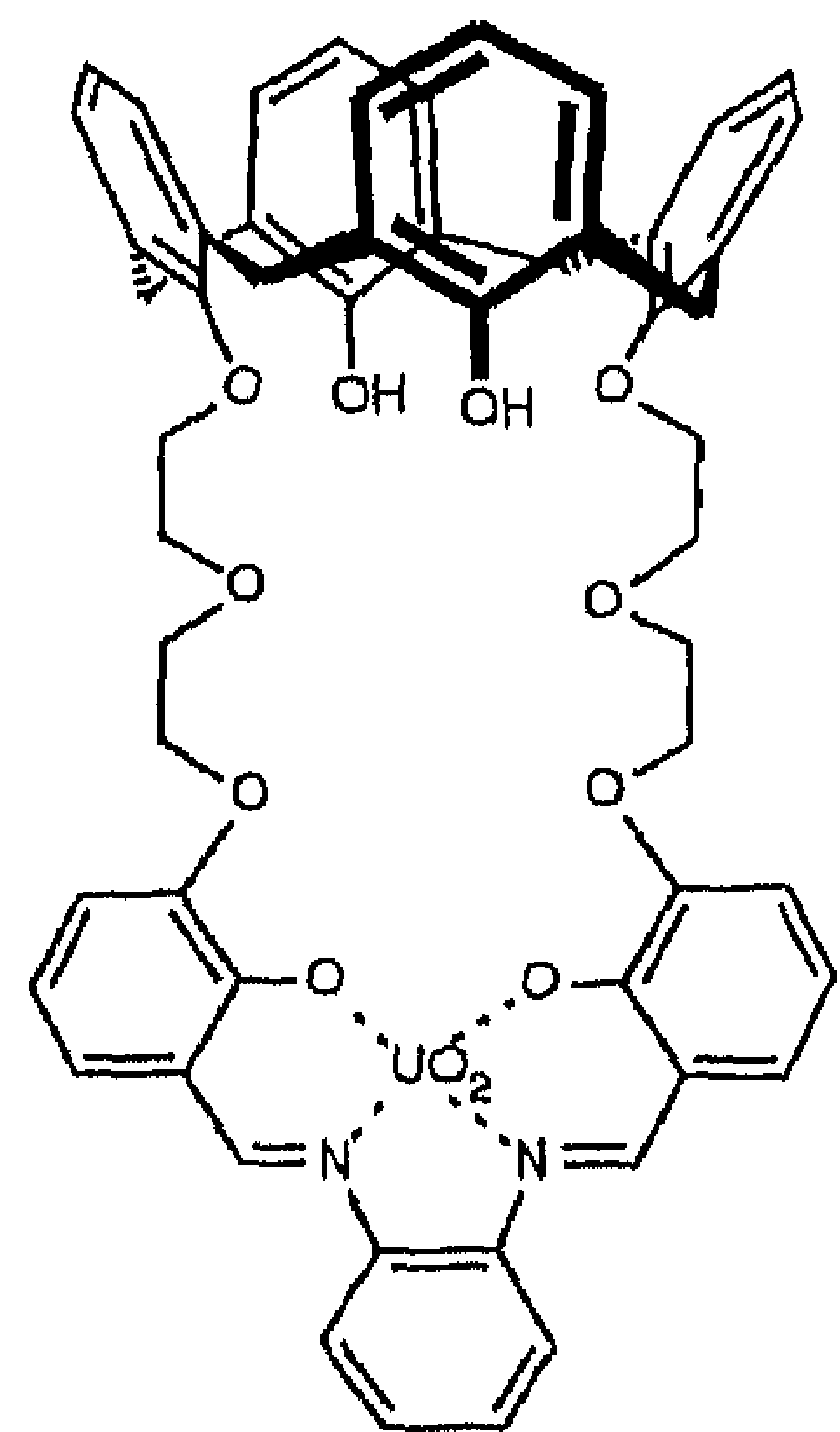

29

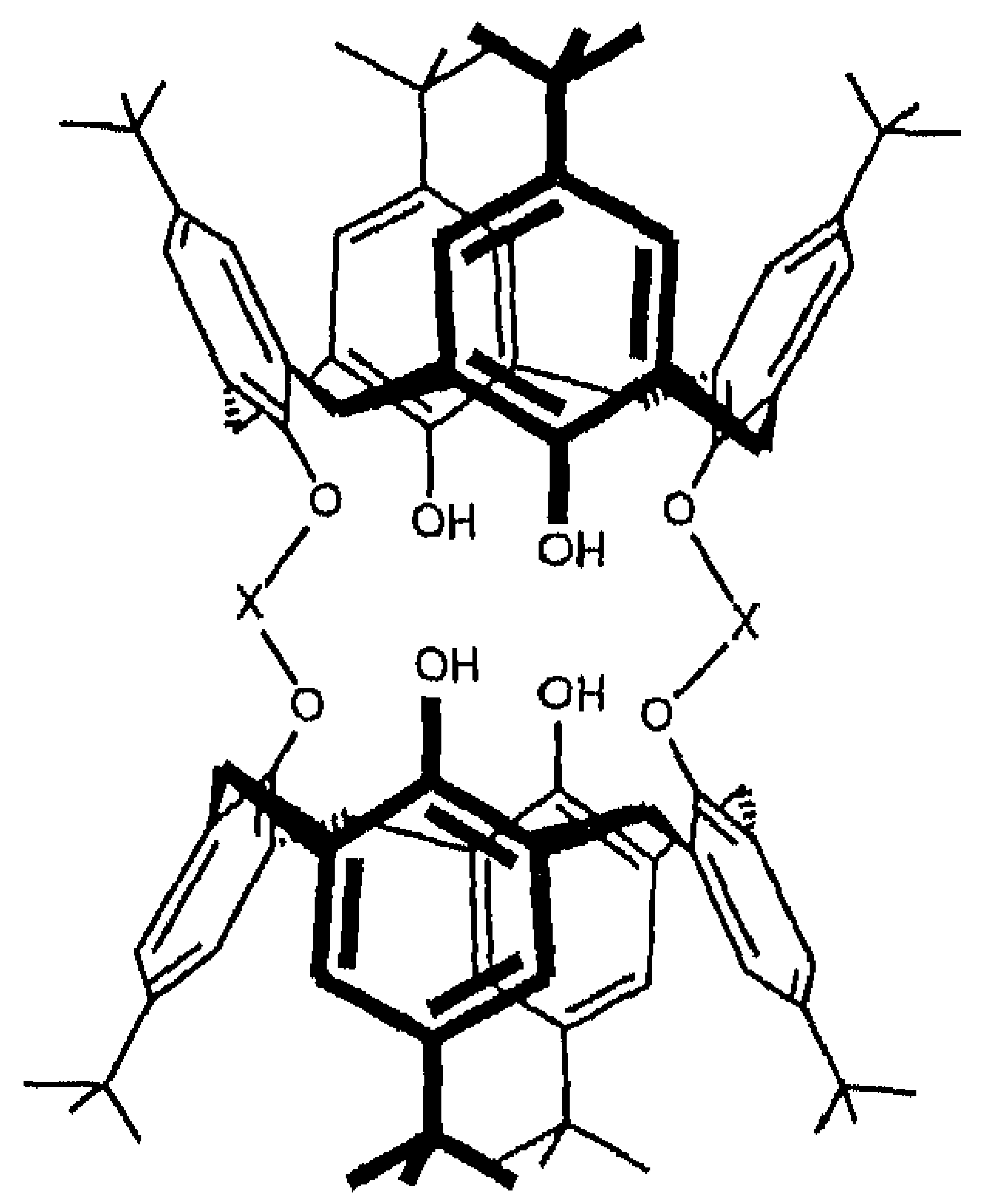

$30 \times=$

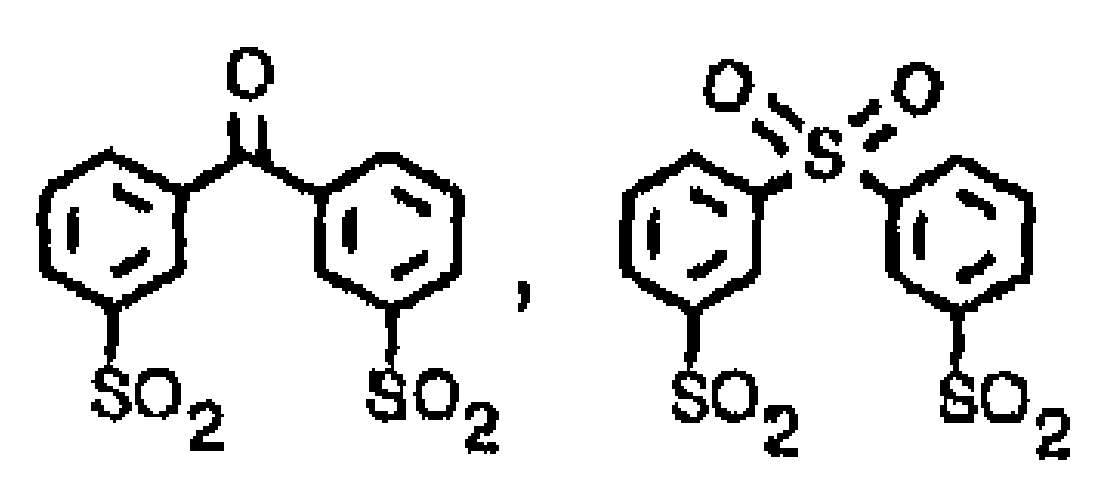




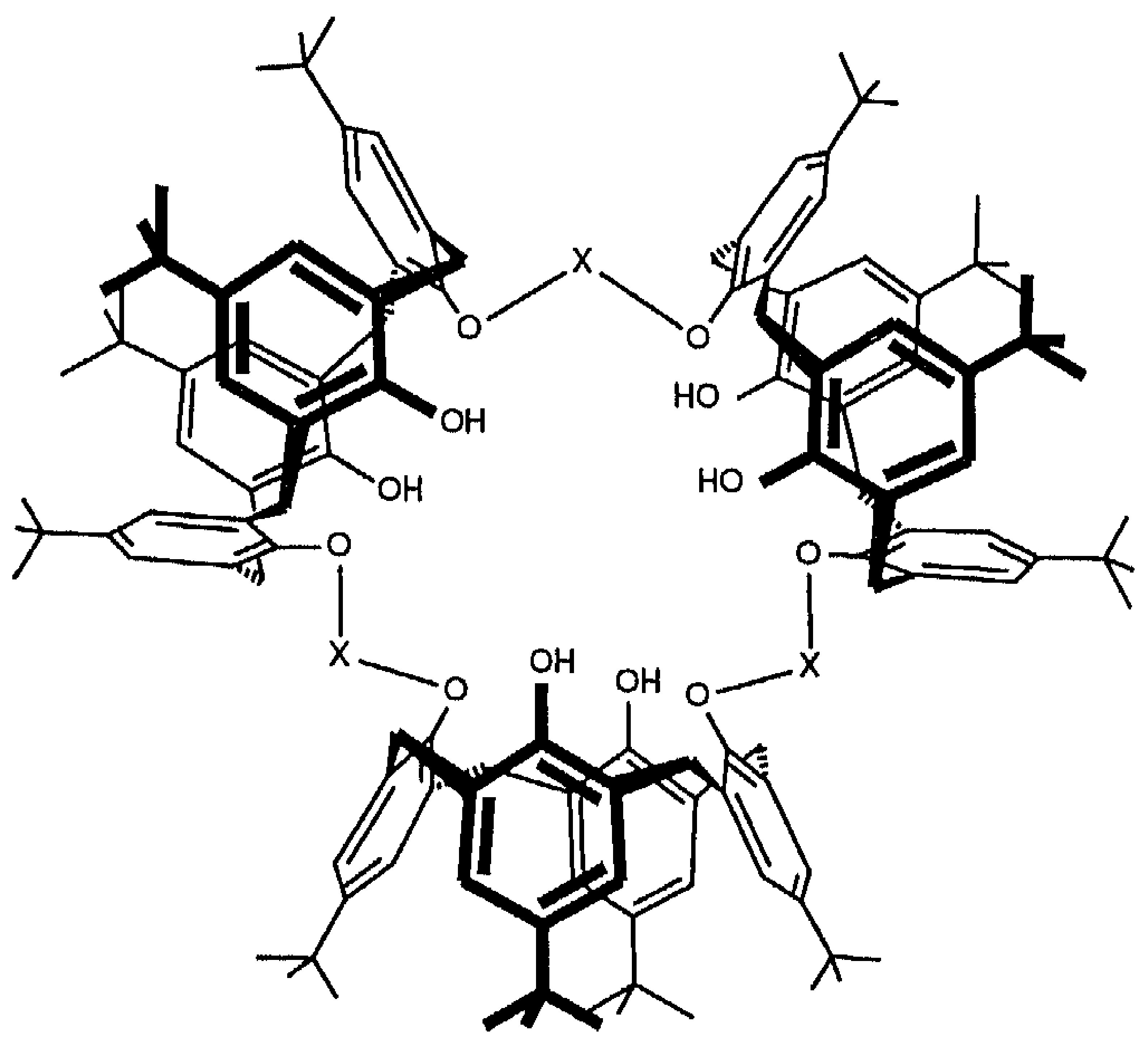

$31 X=\mathrm{O}_{2} \mathrm{~s}-\left(-\mathrm{O}-\mathrm{so}_{2}\right.$

reacts with the unsubstituted $p$-tert-butylcalix[4]arene to yield the dihydroxycalixspherand 27 in $75 \%$ yield, and subsequently the calixarene moiety is further alkylated [30].

\subsection{CALIX[4]ARENES COMBINED WITH ȘALOPHENE UNITS}

Macrocycles that contain a salophene unit in which a uranyl cation is immobilized are very good complexing agents for urea and other neutral molecules containing a nucleophilic center [31]. Coupling of the salophene unit to calix[4]arene 9a yielded compound 29, which is very effective in the transport of urea through supported liquid membranes [32]. Further functionalization of the two remaining hydroxyl groups can lead to compounds that might be used as models for the enzyme urease [33].

\subsection{DOUBLE AND TRIPLE CALIX[4]ARENES}

In a study of alternative ways for the selective functionalization of the lower rim, by letting the unsubstituted calix[4]arene react with electrophiles with two reactive groups, we obtained not only the desired 1,2- and 1,3-bridged calix[4]arenes but in some cases 
also double calix[4] arenes that are coupled by two bridges (compounds 30) [34]. The use of bridging agents that cannot bridge two hydroxyl groups of a calix[4]arene because of the too large distance between the two reactive centers, leads exclusively to double and even triple calix[4]arenes like compound 31 [35].

\subsection{COMBINATION OF CALIX[4]ARENES AND OCTOLS}

The coupling of the tribridged octol $\mathbf{6}$, in which the two free hydroxyl groups have been transformed to oxyacetic acid chlorides, with a 1,3-p-diaminocalix[4]arene, which was obtained after reduction of the corresponding dinitrocompound, yielded compound 32 in $46 \%$ yield [7]. This molecule can be regarded as a first impulse to the synthesis of large unsymmetrical cavities that cannot collapse. Molecules with a large dipole moment will be complexed in such cavities in one favorite orientation. Changing the dipole moment of the guest molecule by external influences will change the orientation of the guest molecule, so that a simple molecular switch would be obtained.

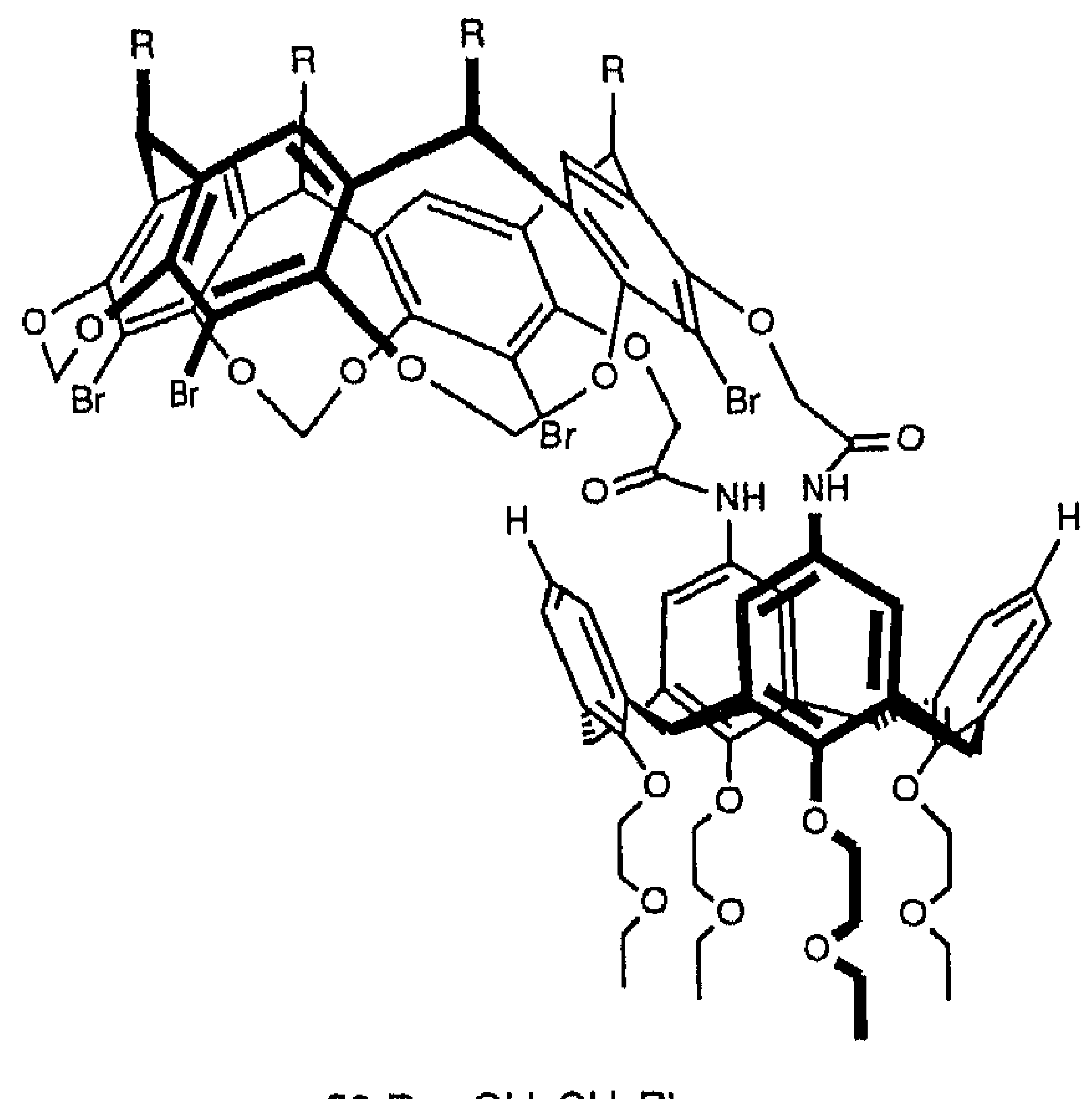

$32 \mathrm{R}=\mathrm{CH}_{2} \mathrm{CH}_{2} \mathrm{Ph}$

5.6 ASSOCIATION OF CALIX[4]ARENES BY NON-COVALENT INTERACTIONS

The calix[4]arene molecule cannot only be used as a building block for new receptor molecules in which it participates in the binding of the guest, but it can also be utilized 
as a molecular platform to which other molecules are attached that provide for the only binding sites. In compound 33, which was synthesized from the already mentioned 1,3-p-diaminocalix[4]arene and 2,4-dichloro-6-methoxy-1,3,5-triazine and subsequent reaction with $n$-butyl amine, the calix[4]arene moiety is only used to position the two binding sites (the triazine rings) close to each other [23]. This molecule binds 5-ethyl5-phenylbarbituric acid (34) with an association constant of $520 \pm 50 \mathrm{M}^{-1}$.

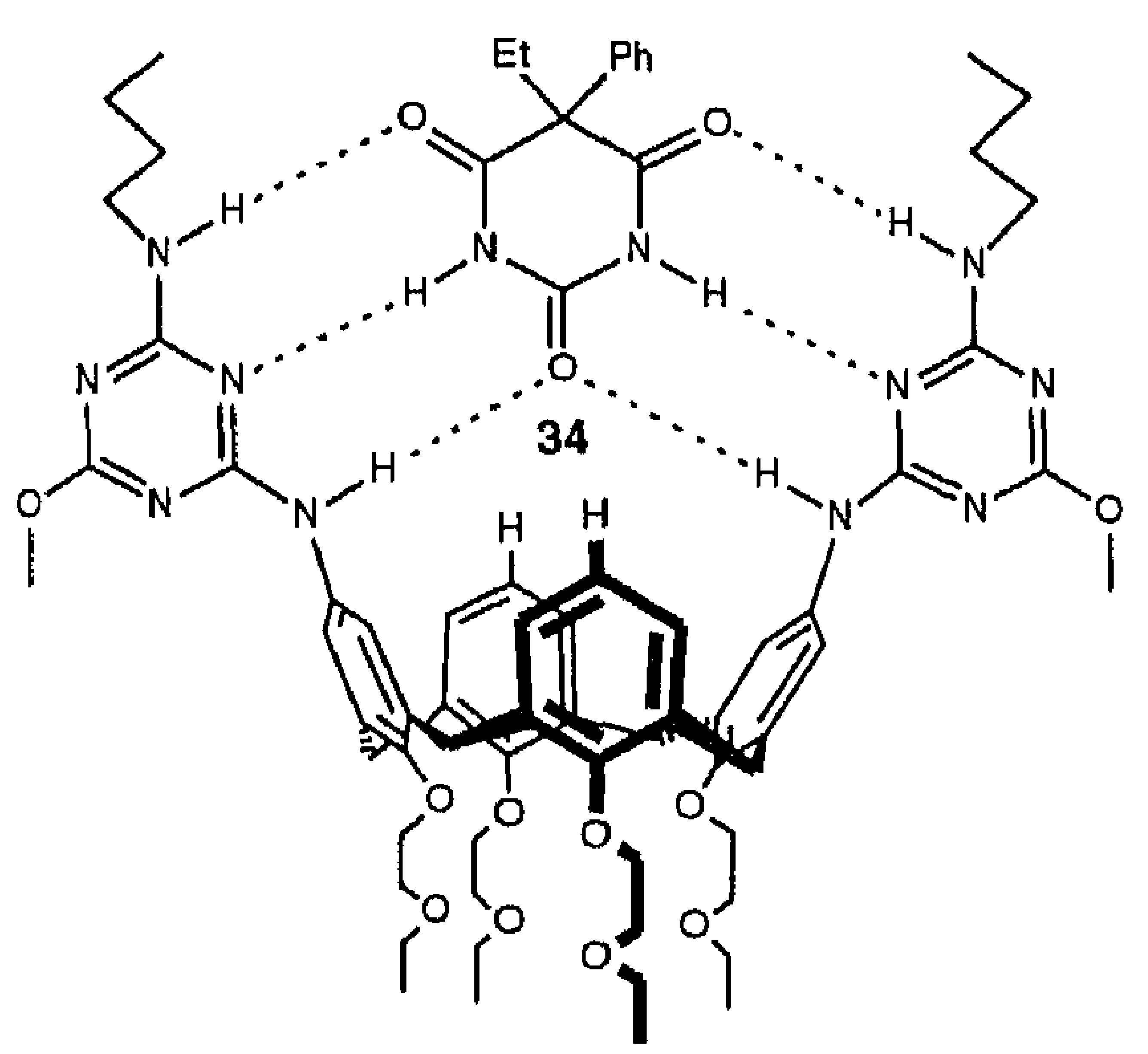

33

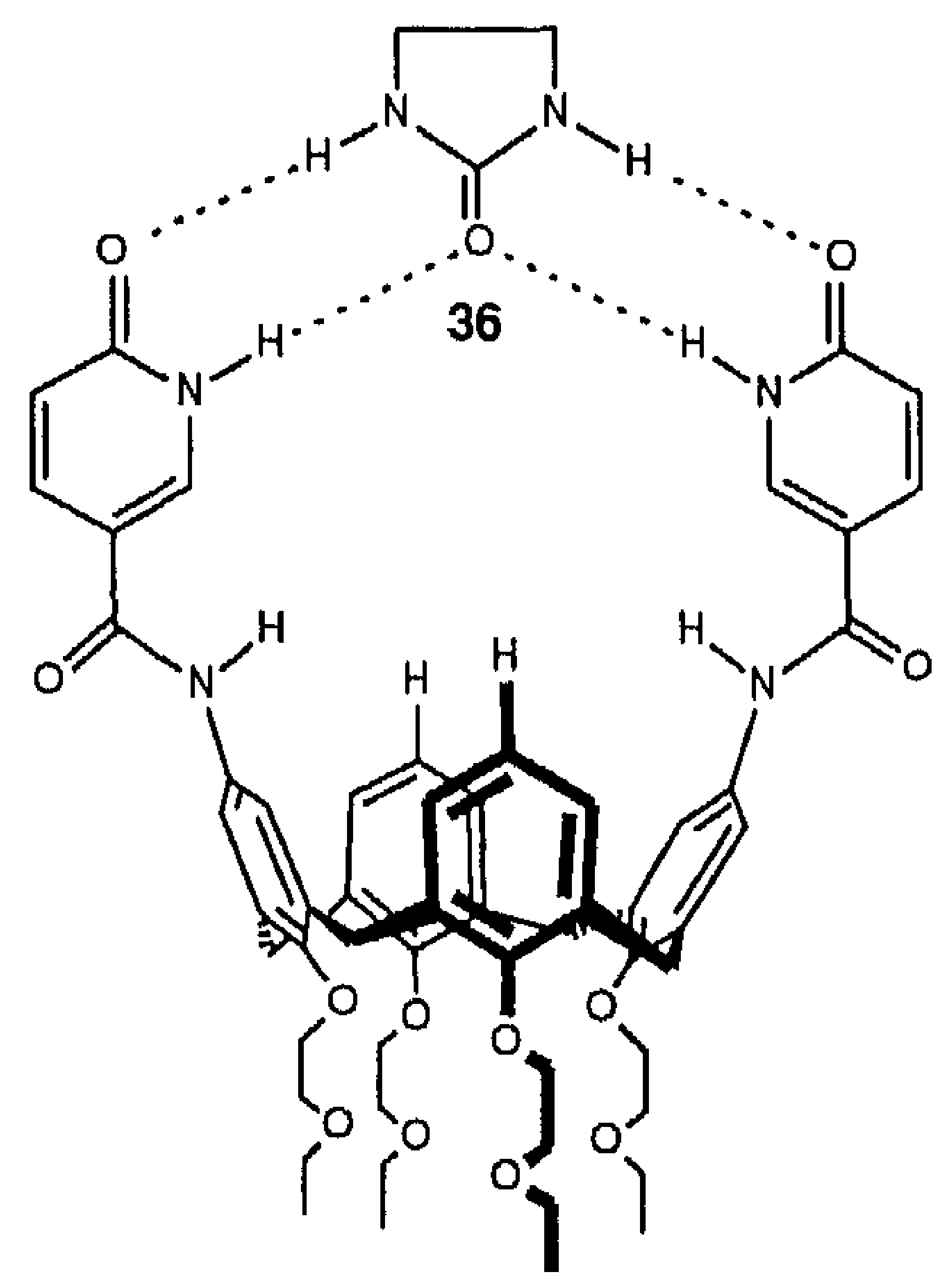

35

A more interesting example is compound 35, which was synthesized from again the same 1,3-p-diaminocalix[4] arene and 6-hydroxynicotinic acid [36]. The four sites for hydrogen bonding in this molecule are slightly more divergent than in compound $\mathbf{3 3}$ and as a consequence it forms large associates in $\mathrm{CDCl}_{3}$ solution. The associates are oligomers of calix[4]arene units, the compound can therefore be regarded as a (supramolecular) polymer. The number and weight average molecular weights of this polymer are $5100 \pm 300$ and $30000 \pm 3000$, respectively. The high ratio between the weight and number average molecular weights indicates that the polymer has a broad mass distribution, and that there is not a favored length of the polymer chains. The polymers are easily broken by adding molecules that can compete for the sites for hydrogen bonding on the calix[4]arenes. Addition of a cyclic urea derivative, 2-imidazolidone (36), leads to the formation of $1: 1$ and $1: 2$ complexes of calix[4]arene and guest molecule. The calix[4]arene can also solubilize urea itself in $\mathrm{CDCl}_{3}$, up to 0.35 molecules of urea per calix[4]arene molecule. 
Compound $\mathbf{3 5}$ opens the way to the development of molecular materials on the basis of intermolecular interactions. We are currently investigating how enough structural information can be incorporated into the monomeric calix[4]arene units so that they will form assemblies with a better defined geometry.

\section{Conclusions}

By the development of new methods for the selective functionalization of calix[4]arenes we have reached the point at which we can shape the calix[4]arene molecule in virtually any way that we would like. This is a prerequisite for the use of calix[4]arenes as building blocks in the synthesis of larger molecules with specific properties. The combination with several other small and well-known building blocks resulted in molecules with very useful complexation properties. We are currently investigating the selective functionalization of other building blocks (octols, cyclodextrins, calix[6]arenes) and the coupling of these building blocks with calix[4]arenes. Undoubtedly this will lead to new compounds with interesting properties. Finally, we are also exploring ways for building well-defined associates of calix[4]arenes on the basis of hydrogen bonds.

\section{Acknowledgments}

The work described in this paper is the result of the efforts of more than 20 coworkers whose names appear in the references of this paper. Our calixarene work is carried out in close collaboration with the University of Parma (Professors Ungaro and Pochini). Financial support from the Netherlands Organization for Scientific Research (NWO), the EEC Science Program and AKZO Research BV Arnhem, The Netherlands is gratefully acknowledged.

\section{References}

1 Breslow, R. (1990) Pure Appl. Chem. 62, 1859-1866.

2 Gutsche, C. D. (1989) 'Calixarenes', Royal Society of Chemistry, Cambridge.

3 Vicens, J, and Böhmer, V. (eds.) (1991) 'Calixarenes. A Versatile Class of Compounds', Kluwer Academic Publishers, Dordrecht.

4 Pregel, M. J. and Bruncel, E. (1991), Can. J. Chem. 69, 130-137. 
5 van Dienst, E., Eissink, I. M., den Hertog, Jr., H. J. and Reinhoudt, D. N., unpublished work.

6 Cram, D. J., Karbach, S., Kim, H.-E., Knobler, C. B., Maverick, E. F., Ericson, J. L. and Helgeson, R. C. (1988) J. Am. Chem. Soc. 110, 2229-2237.

7 Timmerman, P., van Mook, M., Verboom, W. and Reinhoudt, D. N., unpublished results.

8 Casnati, A., Arduini, A., Ghidini, E., Pochini, A. and Ungaro, R. (1991) Tetrahedron 47, 2221-2228.

9 Groenen, L. C., Ruël, B. H. M., Casnati, A., Verboom, W., Pochini, A., Ungaro, R. and Reinhoudt, D. N. (1991) Tetrahedron 47, 8379-8384.

10 a) van Loon, J.-D., Arduini, A., Verboom, W., Ungaro, R., van Hummel, G. J., Harkema, S. and Reinhoudt, D. N. (1989) Tetrahedron Lett. 30, 2681-2684. b) van Loon, J.-D., Arduini, A., Coppi, L., Verboom, W., Pochini, A., Ungaro, R., Harkema, S. and Reinhoudt, D. N. (1990) J. Org. Chem. 55, 5639-5646.

11 Collins, E. M., McKervey, M. A. and Harris, S. J. (1989) J. Chem. Soc., Perkin Trans. 1, 372-374.

12 Groenen, L. C., Ruël, B. H. M., Casnati, A., Timmerman, P., Verboom, W., Harkema, S., Pochini, A., Ungaro, R. and Reinhoudt, D. N. (1991) Tetrahedron Lett. 32, 2675-2678.

13 Goren, Z. and Biali, S. E. (1990) J. Chem. Soc., Perkin Trans. 1, 1484-1487.

14 Ting, Y., Verboom, W., Groenen, L. C., van Loon, J.-D. and Reinhoudt, D. N. (1990) J. Chem. Soc., Chem. Commun., 1432-1433.

15 Gutsche, C. D., Dhawan, B., Levine, J. A., No, K. H. and Bauer, L. J. (1983) Tetrahedron 39, 409-426.

16 Groenen, L. C., van Loon, J. D., Verboom, W., Harkema, S., Casnati, A., Ungaro, R., Pochini, A., Ugozzoli, F. and Reinhoudt, D. N. (1991) J. Am. Chem. Soc. 113, 2385-2392.

17 van Loon, J. D., Groenen, L. C., Wijmenga, S. S., Verboom, W. and Reinhoudt, D. N. (1991) J. Am. Chem. Soc. 113, 2378-2384.

18 a) Araki, K., Iwamoto, K., Shinkai, S. and Matsuda, T. (1989) Chem. Lett., 1747-1750. b) Iwamoto, K., Araki, K. and Shinkai, S. (1991) J. Org. Chem. 56, 4955-4962.

19 Verboom, W., Durie, A., Egberink, R. J. M., Asfari, Z. and Reinhoudt, D. N., J. Org. Chem., in the press.

20 Datta, S., Janssen, R. G., van Loon, J.-D., Verboom, W. and Reinhoudt, D. N., unpublished results.

21 Gutsche, C. D. and Lin, L.-G. (1986) Tetrahedron 42, 1633-1640.

22 Kelderman, E., Derhaeg, L., Heesink, G., Verboom, W., Engbersen, J., van Hulst, 
N., Persoons, A. and Reinhoudt, D. N., manuscript in preparation.

23 Heida, J. F., van Loon, J.-D., Verboom, W. and Reinhoudt, D. N., unpublished results.

24 Ghidini, E., Ugozzoli, F., Ungaro, R., Harkema, S., El-Fadl, A. A. and Reinhoudt, D. N. (1990) J. Am. Chem. Soc. 112, 6979-6985.

25 Sudhölter, E. J. R., van der Wal, P. D., Skowronska-Ptasinska, M., van den Berg, A., Bergveld, P. and Reinhoudt, D. N. (1990) Recl. Trav. Chim. Pays-Bas 109, 222-225.

26 Nijenhuis, W. F., Buitenhuis, E. G., de Jong, F., Sudhölter, E. J. R. and Reinhoudt, D. N. (1991) J. Am. Chem. Soc. 113, 7963-7968.

27 Cram, D. J. and Lein, G. M. (1985) J. Am. Chem. Soc. 107, 3657-3668.

28 a) Reinhoudt, D. N., Dijkstra, P. J., in 't Veld, P. J. A., Bugge, K.-E., Harkema, S., Ungaro, R. and Ghidini, E. (1987) J. Am. Chem. Soc. 109, 4761-4762. b) Dijkstra, P. J., Brunink, J. A. J., Bugge, K.-E., Reinhoudt, D. N., Harkema, S., Ungaro, R., Ugozzoli, F. and Ghidini, E. (1989) J. Am. Chem. Soc. 111, 7567-7575.

29 Groenen, L. C., Harkema, S. and Reinhoudt, D. N., manuscript in preparation.

30 Iwema Bakker, W. I., Ostaszewski, R., Khoo, C., Verboom, W., den Hertog, Jr, H. J. and Reinhoudt, D. N., unpublished results.

31 Van Doorn, A. R., Schaafstra, R., Bos, M., Harkema, S., van Eerden, J., Verboom, W. and Reinhoudt, D. N. (1991) J. Org. Chem. 56, 6083-6094.

32 Nijenhuis, W. F., van Doorn, A. R., Reichwein, A. M., de Jong, F. and Reinhoudt, D. N. (1991) J. Am. Chem. Soc. 113, 3607-3608.

33 Reichwein, A. M., Verboom, W. and Reinhoudt, D. N., unpublished results.

34 van Loon, J.-D., Kraft, D., Ankoné, M. J. K., Verboom, W., Harkema, S., Vogt, W., Böhmer, V. and Reinhoudt, D. N. (1990) J. Org. Chem. 55, 5176-5179.

35 Kraft, D., van Loon, J.-D., Owens, M., Verboom, W., Vogt, W., McKervey, M. A., Böhmer, V. and Reinhoudt, D. N. (1990) Tetrahedron Lett. 31, 4941-4944.

36 Janssen, R. G., van Loon, J.-D., Verboom, W. and Reinhoudt, D. N., unpublished results. 